\title{
2-Aminopyrimidinium Decavanadate: Experimental and Theoretical Characterization, Molecular Docking, and Potential Antineoplastic Activity
}

\author{
Amalia García-García ${ }^{1,2}$ (D) Lisset Noriega ${ }^{3}$, Francisco J. Meléndez-Bustamante ${ }^{3}$, María Eugenia Castro ${ }^{1}(\mathbb{D}$, \\ Brenda L. Sánchez-Gaytán ${ }^{1}$, Duane Choquesillo-Lazarte ${ }^{4}\left(\mathbb{D}\right.$, Enrique González-Vergara ${ }^{1, * \mathbb{C}}$ and \\ Antonio Rodríguez-Diéguez ${ }^{2, *} *$ (i)
}

1 Centro de Química del Instituto de Ciencias, Benemérita Universidad Autónoma de Puebla, 18 sur y Av. San Claudio, Col. San Manuel, Puebla 72570, CP, Mexico; amaliagarcia@correo.ugr.es (A.G.-G.); mareug.castro@correo.buap.mx (M.E.C.); brenda.sanchez@viep.com.mx (B.L.S.-G.)

2 Departamento de Química Inorgánica, Facultad de Ciencias, Universidad de Granada, Av. Fuentenueva S/N, 18071 Granada, Spain

3 Facultad de Ciencias Químicas, Benemérita Universidad Autónoma de Puebla, 18 sur y Av. San Claudio, Col. San Manuel, Puebla 72570, CP, Mexico; lisset.noriegad@alumno.buap.mx (L.N.); francisco.melendez@correo.buap.mx (F.J.M.-B.)

check for updates

Citation: García-García, A.; Noriega, L.; Meléndez-Bustamante, F.J.; Castro, M.E.; Sánchez-Gaytán, B.L.;

Choquesillo-Lazarte, D.; González-Vergara, E.;

Rodríguez-Diéguez, A.

2-Aminopyrimidinium

Decavanadate: Experimental and

Theoretical Characterization,

Molecular Docking, and Potential Antineoplastic Activity. Inorganics 2021, 9, 67. https://doi.org/10.3390/ inorganics 9090067

Academic Editor: Dinorah Gambino

Received: 31 July 2021

Accepted: 26 August 2021

Published: 30 August 2021

Publisher's Note: MDPI stays neutral with regard to jurisdictional claims in published maps and institutional affiliations.

Copyright: (c) 2021 by the authors. Licensee MDPI, Basel, Switzerland. This article is an open access article distributed under the terms and conditions of the Creative Commons Attribution (CC BY) license (https:/ / creativecommons.org/licenses/by/ $4.0 /)$.
4 Laboratorio de Estudios Cristalográficos, IACT, CSIC-UGR, Av. Las Palmeras n4, 18100 Granada, Spain; duane.choquesillo@csic.es

* Correspondence: enrique.gonzalez@correo.buap.mx (E.G.-V.); antonio5@ugr.es (A.R.-D.); Tel.: +52-222-363-0623 (E.G.-V.); +34-958-248-524 (A.R.-D.)

Abstract: The interest in decavanadate anions has increased in recent decades, since these clusters show interesting applications as varied as sensors, batteries, catalysts, or new drugs in medicine. Due to the capacity of the interaction of decavanadate with a variety of biological molecules because of its high negative charge and oxygen-rich surface, this cluster is being widely studied both in vitro and in vivo as a treatment for several global health problems such as diabetes mellitus, cancer, and Alzheimer's disease. Here, we report a new decavanadate compound with organic molecules synthesized in an aqueous solution and structurally characterized by elemental analysis, infrared spectroscopy, thermogravimetric analysis, and single-crystal X-ray diffraction. The decavanadate anion was combined with 2-aminopyrimidine to form the compound [2-ampymH]6[V10O28]-5H2O (1). In the crystal lattice, organic molecules are stacked by $\pi-\pi$ interactions, with a centroid-tocentroid distance similar to that shown in DNA or RNA molecules. Furthermore, computational DFT calculations of Compound $\mathbf{1}$ corroborate the hydrogen bond interaction between pyrimidine molecules and decavanadate anions, as well as the $\pi-\pi$ stacking interactions between the central pyrimidine molecules. Finally, docking studies with test RNA molecules indicate that they could serve as other potential targets for the anticancer activity of decavanadate anion.

Keywords: decavanadate; 2-aminopyrimidinium; experimental and theoretical characterization; DFT; docking RNA/DNA

\section{Introduction}

Polyoxidometalates (POMs) are defined as clusters made from early transition-metals, typically $\mathrm{d}^{0}$ species $\mathrm{V}(\mathrm{V}), \mathrm{Nb}(\mathrm{V}), \mathrm{Ta}(\mathrm{V}), \mathrm{Mo}(\mathrm{VI})$, and $\mathrm{W}(\mathrm{VI})$, bridged by oxide anions. This class of compounds is highly interesting in molecular structural variety, reactivity, and applications in analytical chemistry, catalysis, medicine, and materials research [1]. POMs have great potential in biological applications, since every aspect that involves the interaction of POM with biological target macromolecules could be modified to improve their beneficial effects on a biological system. Thus, interesting POMs with anticancer [2] and antibiotic activities [3], among others, have been obtained to date. 
In this context, the colorless aqueous solution of vanadate(V) turns orange as it acidifies. This phenomenon is associated with condensation reactions carried out by vanadate ions depending on the acidity range of the solution. Thus, at $\mathrm{pH} \approx 6$, the orange solution indicates that the decavanadate anion, $\left[\mathrm{H}_{n} \mathrm{~V}_{10} \mathrm{O}_{28}\right]^{(6-n)-}$ with $n=0-4$, has been formed $[4,5]$. These clusters have attracted much interest due to their potential applications in a wide range of uses such as sensors [6], batteries [7-9], catalysts [10-12], or metallodrugs [13-15].

In particular, decavanadates have recently attracted attention due to their medicinal and biochemical behavior, since they have an important role in biological systems by having the ability to interact with proteins, enzymes, and cell membranes [16].

More than forty years ago, vanadate was first found as an impurity in commercial ATP obtained from horse skeletal muscle and was initially identified as a muscle inhibition factor by inhibiting the activity of the sodium pump [17]. Subsequently, the first enzyme that decavanadate was able to inhibit, the rabbit skeletal muscle adenylate kinase, was reported. After that, many enzymes have been found that can be inhibited by this decameric species, such as hexokinase, phosphofructokinase, inositol phosphate metabolism enzymes, or nicotinamide adenine dinucleotide (NADH)-vanadate reductase [18].

Due to the high negative charge of decavanadate, this species can interact with a multitude of molecules such as proteins, counterions, or lipid structures, affecting many biological processes such as muscle contraction, calcium homeostasis, necrosis, actin polymerization, oxidative stress markers, or glucose uptake, among others [19]. As a result, different compounds based on decavanadate and cationic organic ligands have been published in recent years, which can decrease glycemia [20-22], induce neuronal and cognitive restoration mechanisms to treat metabolic syndrome [13], affect the growth of protozoan parasites and bacteria [23-26], or show antitumor activity [27,28]. For example, the compound $\mathrm{Mg}\left(\mathrm{H}_{2} \mathrm{O}\right)_{6}\left(\mathrm{C}_{4} \mathrm{~N}_{2} \mathrm{H}_{7}\right)_{4} \mathrm{~V}_{10} \mathrm{O}_{28} \cdot 4 \mathrm{H}_{2} \mathrm{O}$ demonstrated dose-dependent antiproliferative activity on human cancer cells U87, IGR39, and MDA-MB-231 [29].

Previous works with Adenine and Cytosine have shown a hydrogen bond interaction with the decavanadate anion $[6,30,31]$. Thus, to obtain new bioactive compounds based on the decavanadate cluster, one organic ligand with potential biological activity was chosen. Here, we report the deployment of 2-aminopyrimidine, which is susceptible to protonation and can interact with the decavanadate anion. Recently, structures formed by decavanadate and ligands with nitrogenous groups with promising antidiabetic and anticancer properties have been published [22,29,32-34]. In addition, within the family of $\mathrm{N}$-heterocyclic compounds, pyrimidines and their derivatives are an important class of compounds in medicinal chemistry [35-37].

In this way, a new member of a family of compounds based on decavanadate was obtained. Decavanadate anion interacts with a 2-aminopyrimidine ligand to afford a crystalline compound with the formula [2-ampymH $]_{6}\left[\mathrm{~V}_{10} \mathrm{O}_{28}\right] \cdot 5 \mathrm{H}_{2} \mathrm{O}(\mathbf{1})$. The structural characterization of the compound was carried out by elemental analysis, infrared spectroscopy, thermogravimetric analysis, and single-crystal X-ray diffraction. In addition, the compound was studied using Density Functional Theory (DFT) computational methods. The frontier molecular orbitals and global reactivity indexes were analyzed for showing interesting characteristics of the donor-acceptor interactions. The insights about the compounds' reactivity were corroborated by analyzing the non-covalent interactions using the AIM approach.

On the other hand, since Sciortino et al. [38] recently published the interaction of decavanadate with G-actin protein with docking calculations, in this work, docking studies using small RNA and DNA molecules were used to test the hypothesis that the attributed anticancer activity of decavanadate could be due to interaction with these critical molecules. Structurally, the compound has a set of hydrogen bonds and $\pi-\pi$ interactions resembling those found in DNA/RNA molecules, opening the field of POM to RNA interactions as potential target molecules for cancer treatment. 


\section{Results}

\subsection{Structural Description of [2-ampym $\mathrm{H}_{6}\left[\mathrm{~V}_{10} \mathrm{O}_{28}\right] \cdot 5 \mathrm{H}_{2} \mathrm{O}$ (1)}

The decavanadate anion is a very useful cluster in coordination chemistry as a building block for various structures. Since they have a high negative charge and oxygen-rich surfaces, interactions between this anion and metals or organic ligands are easily formed by coordination or hydrogen bonds [39]. Based on this cluster, the crystal structure of a new compound with a cationic ligand was determined in the present study. Table 1 presents the corresponding crystal data, and Tables S1-S7 in the supplementary section contain additional crystallographic information.

Table 1. Crystal data and structure refinement for Compound $\mathbf{1 .}$

\begin{tabular}{|c|c|}
\hline Compound & 1 \\
\hline Empirical formula & $\mathrm{C}_{24} \mathrm{H}_{46} \mathrm{~N}_{28} \mathrm{O}_{33} \mathrm{~V}_{10}$ \\
\hline Formula mass $\left(\mathrm{g} \cdot \mathrm{mol}^{-1}\right)$ & 1764.20 \\
\hline CCDC & 2099300 \\
\hline Crystal system & Triclinic \\
\hline Space group & $P \overline{1}$ \\
\hline $\mathrm{a}(\AA)$ & $9.783(5)$ \\
\hline$b(\AA)$ & $11.309(5)$ \\
\hline$c(\AA)$ & $12.853(5)$ \\
\hline$\alpha\left(^{\circ}\right)$ & $110.166(5)$ \\
\hline$\beta\left({ }^{\circ}\right)$ & $95.645(5)$ \\
\hline$\lambda\left({ }^{\circ}\right)$ & $97.551(5)$ \\
\hline Volume $\left(\AA^{3}\right)$ & $1307.4(10)$ \\
\hline $\mathrm{Z}$ & 2 \\
\hline Density $($ calcd $)\left(\mathrm{g} \cdot \mathrm{cm}^{-3}\right)$ & 2.063 \\
\hline$\mu(\mathrm{Mo} / \mathrm{CuK} \alpha)\left(\mathrm{mm}^{-1}\right)$ & 1.815 \\
\hline Temperature (K) & $300(2)$ \\
\hline $\mathrm{GoF}$ on $\mathrm{F}^{2 \mathrm{a}}$ & 1.065 \\
\hline $\mathrm{R}_{1}[1>2 \sigma(\mathrm{I})]^{\mathrm{b}}$ & 0.0386 \\
\hline $\mathrm{R}_{1}$ [all data] ${ }^{\mathrm{b}}$ & 0.0621 \\
\hline $\mathrm{wR}_{2}[1>2 \sigma(\mathrm{I})]^{\mathrm{c}}$ & 0.0821 \\
\hline $\mathrm{wR}_{2}$ [all data] ${ }^{\mathrm{c}}$ & 0.0958 \\
\hline
\end{tabular}

Compound 1 crystallizes in the $P \overline{1}$ space group of the triclinic system and consists of a three-dimensional supramolecular structure, where units of $\left[\mathrm{V}_{10} \mathrm{O}_{28}\right]^{6-}$ interact with the cationic ligand 2-aminopyrimidinium, [2-ampymH ${ }^{+}$and crystallization water molecules through hydrogen bonds. The asymmetric unit contains half of a decavanadate anion arranged in an inversion center, three independent molecules of [2-ampymH $]^{+}$(named as $\mathrm{A}$, $\mathrm{B}$, and $\mathrm{C}$ ) protonated in the N3 position, and two and a half crystallization water molecules (two of them with $100 \%$ occupancy and one with occupancy set at $50 \%$ ). Therefore, the (6-) charge of the decavanadate cluster is stabilized by six [2-ampymH $]^{+}$cations, which are arranged on both sides of the cluster interacting by hydrogen bonds. Thus, the formula established by monocrystal X-ray diffraction was [2-ampymH $]_{6}\left[\mathrm{~V}_{10} \mathrm{O}_{28}\right] \cdot 5 \mathrm{H}_{2} \mathrm{O}$ (Figure 1).

The protonation effect of the 2-ampym ligand mainly results in a variation in the internal angles N2-C1-N3 and, to a lesser extent, in the angles C1-N2-C2 and C1-N3-C4. Table 2 shows these angles compared with the values given by J. Scheinbeim et al. for a non-protonated 2-ampym molecule [40]. Protonation also affects the distances between the atoms within the cation. Specifically, there is a shortening of the N1-C1 bond, from $1.342 \AA$ for the ligand to $1.317 \AA$ on average for the cation. In addition, in the 2-ampym ligand, the N2-C2 and N3-C4 bonds are symmetrical, with a value of $1.331 \AA$, while, N3-C4 bond is greater for the protonated form than the N2-C2 one (1.351 $\AA$ versus $1.323 \AA$ on average, respectively). 


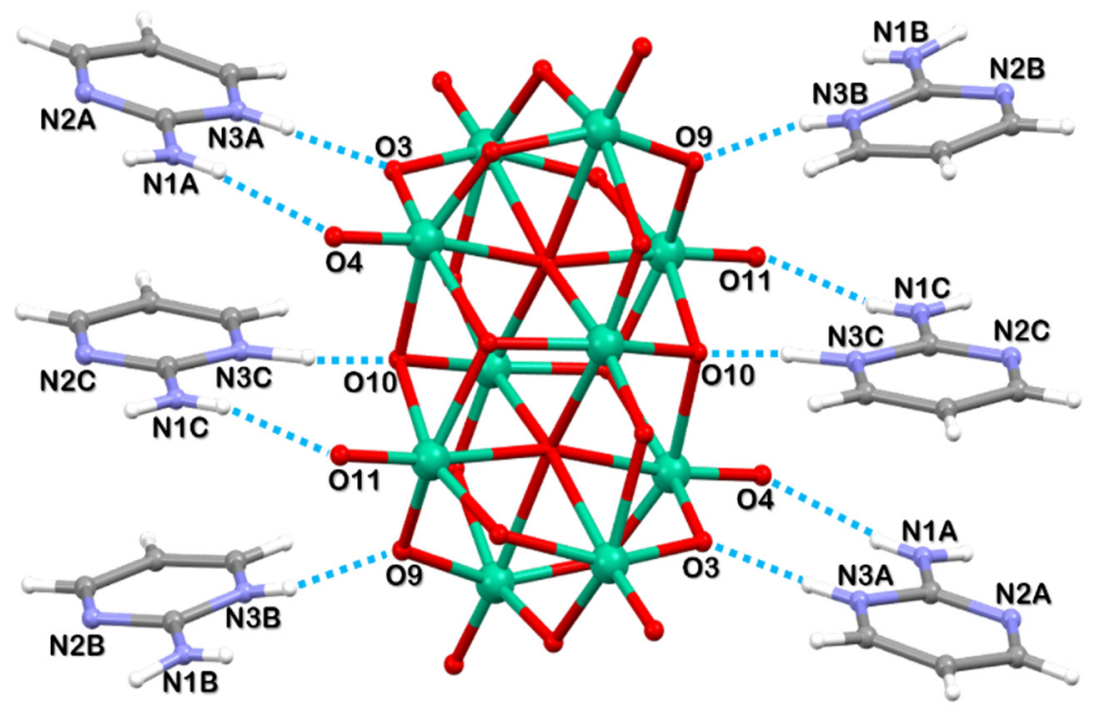

Figure 1. Structure of [2-ampymH $]_{6}\left[\mathrm{~V}_{10} \mathrm{O}_{28}\right] \cdot 5 \mathrm{H}_{2} \mathrm{O}(\mathbf{1})$. The hydrogen bonds among [2-ampymH] ${ }^{+}$ cations and decavanadate anion are shown (blue dashed line). Water molecules have been omitted for clarity. Vanadium atoms are represented in green.

Table 2. Difference between the angles $\left(\Delta^{\circ}\right)$ of the neutral 2-ampym molecule and the cations A, B, and $\mathrm{C}$ of the protonated ligand in Compound $\mathbf{1 .}$

\begin{tabular}{cccc}
\hline Angle & {$[2-A m p y m H]^{+}{ }^{\left({ }^{\circ}\right.}$} & 2-Ampym $\left(^{\circ}\right)$ & $\boldsymbol{\Delta}^{\circ}$ \\
\hline N2A-C1A-N3A & 121.3 & 125.2 & 3.9 \\
N2B-C1B-N3B & 120.9 & & 4.3 \\
N2C-C1C-N3C & 123.2 & 115.7 & 2 \\
C1A-N2A-C2A & 117.3 & & 1.6 \\
C1B-N2B-C2B & 117.3 & & 1.6 \\
C1C-N2C-C2C & 116.6 & 116.2 & 0.9 \\
C1A-N3A-C4A & 120.7 & & 4.5 \\
C1B-N3B-C4B & 120.9 & & 4.7 \\
C1C-N3C-C4C & 118.4 & 2.2 \\
\hline
\end{tabular}

The decavanadate cluster comprises ten edge-sharing $\mathrm{VO}_{6}$ octahedra, containing ten vanadium atoms and twenty-eight oxygen atoms. In total, the cluster possesses sixty V-O bonds which can be differentiated by their bond distances. First, two oxygen atoms are located inside the polyanion $\left(\mathrm{O}_{\mathrm{c}}\right)$ bonded to six vanadium atoms, each one with the largest bond distance in the range of 2.106-2.340 $\AA$. Four other oxygen atoms are arranged on the surface $\left(\mathrm{O}_{\mathrm{b} 1}\right)$ and coordinate to three vanadium atoms each, with bond lengths of $\mathrm{V}-\mathrm{O}_{\mathrm{b} 1}$ in the range of 1.900-2.084 $\AA$. Fourteen oxygen atoms at the corners $\left(\mathrm{O}_{\mathrm{b} 2}\right)$ coordinate to two vanadium atoms each, where $\mathrm{V}-\mathrm{O}_{\mathrm{b} 2}$ bond length distances are ranged from 1.684 to $2.069 \AA$ A Lastly, eight terminal oxygen atoms $\left(\mathrm{O}_{\mathrm{t}}\right)$ are coordinated to only one vanadium each, and the $\mathrm{V}=\mathrm{O}_{\mathrm{t}}$ distance is the smallest one with values in the range of 1.595-1.611 $\AA$. These bond distances agree with other $\left[\mathrm{V}_{10} \mathrm{O}_{28}\right]^{6-}$ anions reported in the literature [41-44]. Bond lengths are listed in Table S3.

The supramolecular structure is dominated by hydrogen bonds of type $\mathrm{N}-\mathrm{H} \cdots \mathrm{N}$, $\mathrm{N}-\mathrm{H} \cdots \mathrm{O}$, and $\mathrm{O}-\mathrm{H} \cdots \mathrm{O}$, in addition to $\pi$-stacking interactions between pyrimidine rings. On the one hand, as shown in Figure 2, the decavanadate anion interacts by hydrogen bonds of type $\mathrm{N}-\mathrm{H} \cdots \mathrm{O}$ with six [2-ampymH] ${ }^{+}$cations: two hydrogen bonds are formed thanks to $\mathrm{N} 1$ and N3 atoms of molecules $\mathrm{A}$ and $\mathrm{C}$, giving rise to a $R_{2}^{2}(8)$ ring motif, according to the nomenclature of Etter et al. [45], while molecule B only forms one hydrogen bond through the N3 atom. Furthermore, [2-ampymH $]^{+}$cations interact with each other by hydrogen bonds, where $\mathrm{N} 2$ atoms of the rings act as acceptors and $\mathrm{N} 1$ atoms of the amino groups are 
the donors, forming a $R_{2}^{2}(8)$ ring motif. The distances and angles of the hydrogen bonds are shown in Table 3.

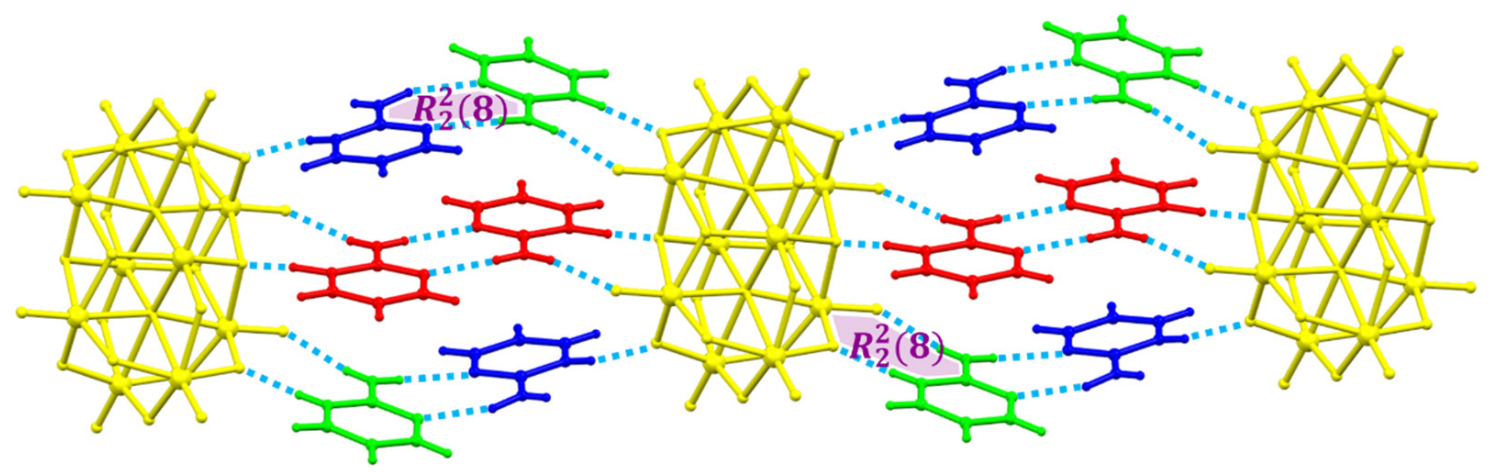

Figure 2. Partial supramolecular structure of Compound 1 based on hydrogen bonds (blue dashed line) among the [2ampymH $]^{+}$cations and decavanadate anions. The structure is colored by symmetric equivalence. $\mathrm{C}$ cations (in red) form hydrogen bonds with each other, while A and B cations (in green and blue, respectively) interact between them.

Table 3. Distances $(\AA)$ and angles $\left(^{\circ}\right)$ of the hydrogen bonds of Compound 1.

\begin{tabular}{|c|c|c|c|c|}
\hline$D-H \cdots A^{b}$ & D-H & $\mathbf{H} \cdots \mathbf{A}$ & D-H $\cdots A$ & Angle $\left({ }^{\circ}\right)$ \\
\hline C2A-H2A $\cdots \mathrm{O} 12$ & 0.93 & 2.57 & $3.176(4)$ & 122.9 \\
\hline $\mathrm{C} 3 \mathrm{~A}-\mathrm{H} 3 \mathrm{~A} \cdots \mathrm{O} 5\left({ }^{\mathrm{i}}\right)$ & 0.93 & 2.28 & $3.133(4)$ & 152.6 \\
\hline N1A-H1AA $\cdots$ N2B $\left({ }^{\mathrm{ii}}\right)$ & 0.83 & 2.17 & $2.997(4)$ & 171.8 \\
\hline N1A-H1AB $\cdots$ O4(iii) & 0.79 & 2.15 & $2.933(4)$ & 171.2 \\
\hline N3A-H3AA ‥O3(iii) & 0.85 & 1.80 & $2.650(3)$ & 174.1 \\
\hline N1B-H1BA $\cdots$ N2A(ii $)$ & 0.93 & 2.14 & $3.043(4)$ & 165.6 \\
\hline N1B-H1BB $\cdots \mathrm{O} 1 \mathrm{~W}$ & 0.70 & 2.34 & $3.024(6)$ & 168.1 \\
\hline N3B-H3BA $\cdots$ O9 & 0.78 & 1.87 & $2.625(3)$ & 163.2 \\
\hline N1C-H1CA $\cdots$ N2C $\left({ }^{\text {iv }}\right)$ & 0.81 & 2.14 & $2.954(4)$ & 179.6 \\
\hline N1C-H1CB $\cdots \mathrm{O} 11\left(^{\mathrm{v}}\right)$ & 0.81 & 2.10 & $2.896(3)$ & 168.8 \\
\hline N3C-H3CA $\cdots$ O 10 & 1.09 & 1.49 & $2.585(3)$ & 174.9 \\
\hline O1W-H1WA $\cdots$ O3W(ii) & 0.85 & 2.36 & $3.162(13)$ & 157.2 \\
\hline O1W-H1WB $\cdots \mathrm{O} 1$ & 0.85 & 2.29 & $3.083(4)$ & 154.4 \\
\hline $\mathrm{O} 2 \mathrm{~W}-\mathrm{H} 2 \mathrm{WA} \cdots \mathrm{O} 11\left(^{\mathrm{vi}}\right)$ & 0.85 & 2.79 & $3.352(7)$ & 125.5 \\
\hline $\mathrm{O} 2 \mathrm{~W}-\mathrm{H} 2 \mathrm{WB} \cdots \mathrm{O} 11\left({ }^{\mathrm{ii}}{ }^{\prime}\right.$ & 0.85 & 2.09 & $2.729(8)$ & 131.2 \\
\hline O3W-H3WA $\cdots$ O6 & 0.85 & 2.30 & $3.049(9)$ & 147.7 \\
\hline O3W-H3WA $\cdots$ O1W(ii) & 0.85 & 2.64 & $3.162(13)$ & 121.3 \\
\hline $\mathrm{O} 3 \mathrm{~W}-\mathrm{H} 3 \mathrm{WB} \cdots \mathrm{O} 4\left({ }^{\mathrm{i}}\right)$ & 0.85 & 2.30 & $3.143(11)$ & 174.7 \\
\hline
\end{tabular}

Symmetry operations: (i) $=\mathrm{x},-\mathrm{y}, 1-\mathrm{z}$; (ii) $=2-\mathrm{x}, 1-\mathrm{y}, 2-\mathrm{z}$; (iii) $=1-\mathrm{x},-\mathrm{y}, 1-\mathrm{z}$; (iv) $=1-\mathrm{x},-\mathrm{y},-\mathrm{z}$ (v) $=2-\mathrm{x}, 1-\mathrm{y}, 1-\mathrm{z}$; (vi) $=+\mathrm{x},-1+\mathrm{y},+\mathrm{z} ;{ }^{b}$ D: donor; H: hydrogen; A: acceptor.

On the other hand, due to the arrangement of [2-ampymH $]^{+}$cations, $\pi-\pi$ stacking interactions are formed between pyrimidine rings, by forming a chain of six rings that repeats infinitely in space (Figure 3), with an average distance between centroids of $3.617 \AA$, which falls within the range of a $\pi-\pi$ interaction. Some of the rings are stacked in an aligned way, while others form a $\pi-\pi$ stacking shifted parallel about $22^{\circ}$, also producing a shorter distance between centroids because $\pi-\sigma$ attraction forces predominate in this arrangement [46]. A similar structure has been published by S. Sedghiniya et al. [6], in which decavanadate anion interacts by hydrogen bonds with cations of Adenine, one of the five nitrogenous bases that form DNA and RNA. Similarly, in this structure, the cations interact with each other by hydrogen bonds and $\pi-\pi$ stacking interactions, with a centroid-to-centroid distance of $3.5 \AA$ and a displacement angle of approximately $24^{\circ}$. 


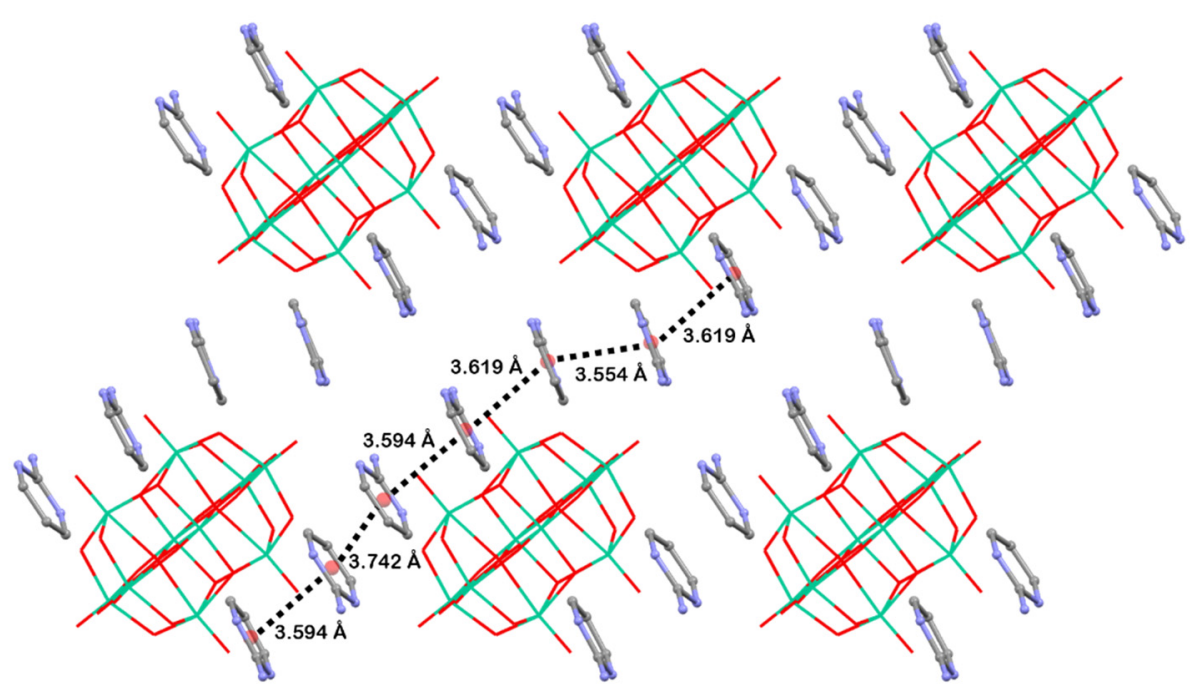

Figure 3. Partial supramolecular structure of Compound 1 where $\pi-\pi$ stacking interactions between the aromatic rings of pyrimidine and the distance between centroids are shown (black dashed line). Vanadium atoms are represented in green.

This arrangement is clearly reminiscent of DNA structure, a polymer formed by base pairs that interact with hydrogen bonds and are stacked by $\pi-\pi$ stacking interactions with a distance between centroids of $3.4 \AA$ A Similarly, in Compound 1, [2-ampymH $]^{+}$molecules interact by hydrogen bonds and are stacked by $\pi-\pi$ stacking interactions with a distance between centroids of approximately $3.6 \AA$ (Figure 4).

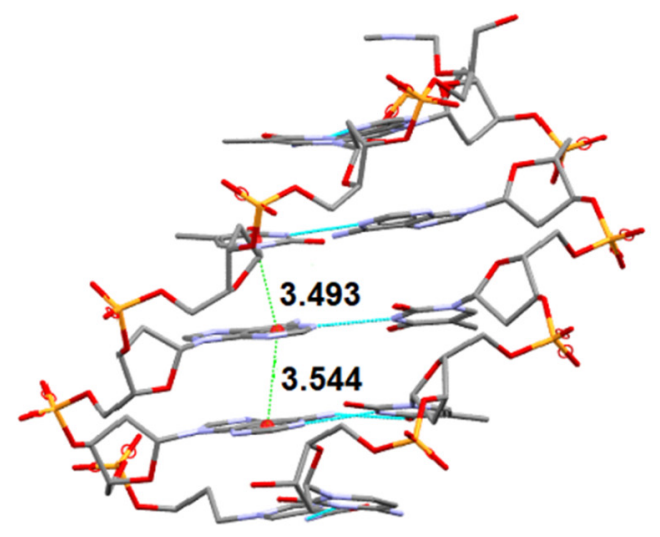

(a)

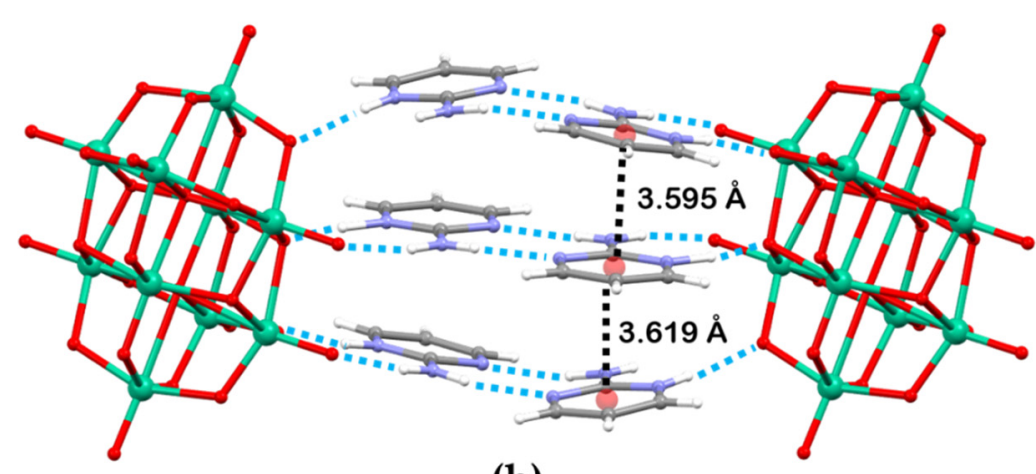

(b)

Figure 4. (a) Small fragment of DNA (1BNA) and (b) Compound 1 show a similar structure, with distances between centroids in the same range. Vanadium atoms are represented in green. 
Lastly, this structure contains water molecules of crystallization (Figure 5). Two of the water molecules of the unit cell (O1W and $\mathrm{O} 3 \mathrm{~W}$ ) are arranged between the decavanadate and the cations in general positions, while the third one $(\mathrm{O} 2 \mathrm{~W})$ is located at the apex, making its contribution to the unit cell $50 \%$. These water molecules form hydrogen bonds within the structure, helping to stabilize it. All distances of hydrogen bonds along with their angles are found in Table 3.

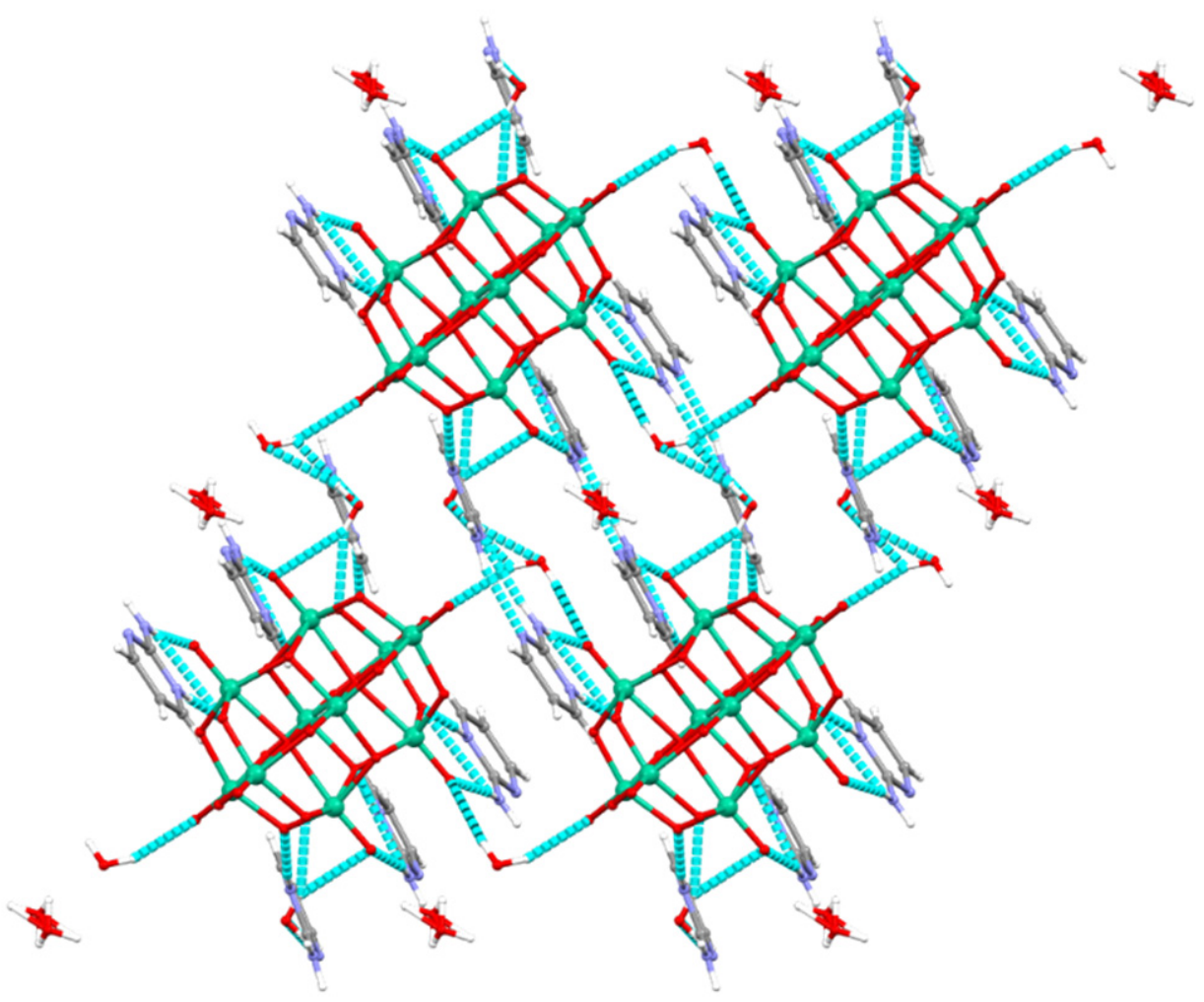

Figure 5. View of the supramolecular structure along the crystallographic $a$-axis, where all hydrogen bonds forming in Compound $\mathbf{1}$ can be observed (blue dashed line). Vanadium atoms are represented in green.

\subsection{Infrared (IR) Spectroscopy}

At the top of the 2-ampym ligand spectrum (Figure 6) were the characteristic bands at 3331 and $3165 \mathrm{~cm}^{-1}$ that belong to the stretching vibration modes of the $\mathrm{N}-\mathrm{H}$ and C-H bonds, respectively. In addition, the bending vibration modes appeared at 1645 and $1128 \mathrm{~cm}^{-1}$, respectively. Lower wavenumbers show the characteristic bands of the aromatic pyrimidine ring with peaks at $1556,1469,1356,794$, and $555 \mathrm{~cm}^{-1}$, belonging to the C-N, $\mathrm{C}=\mathrm{C}, \mathrm{C}-\mathrm{C}$, and CCC bonds, respectively [47-49]. As for the spectrum of Compound 1, it was possible to see both characteristic bands of the ligand 2-aminopyrimidine and the bands belonging to the different vibration modes of the $\mathrm{V}-\mathrm{O}$ bond of decavanadate anion. Although the band belonging to the vibration of the $\mathrm{O}-\mathrm{H}$ bond was not distinguished precisely, there was a wideband between 3400 and $2900 \mathrm{~cm}^{-1}$, which could be assigned to water molecules in the structure. In addition, there was a slight displacement of the bands belonging to the $\mathrm{V}=\mathrm{O}$ and $\mathrm{N}-\mathrm{H}$ groups, so the interaction between both molecules was weak, mainly due to hydrogen bonds. Main IR bands are collected in Table 4. 


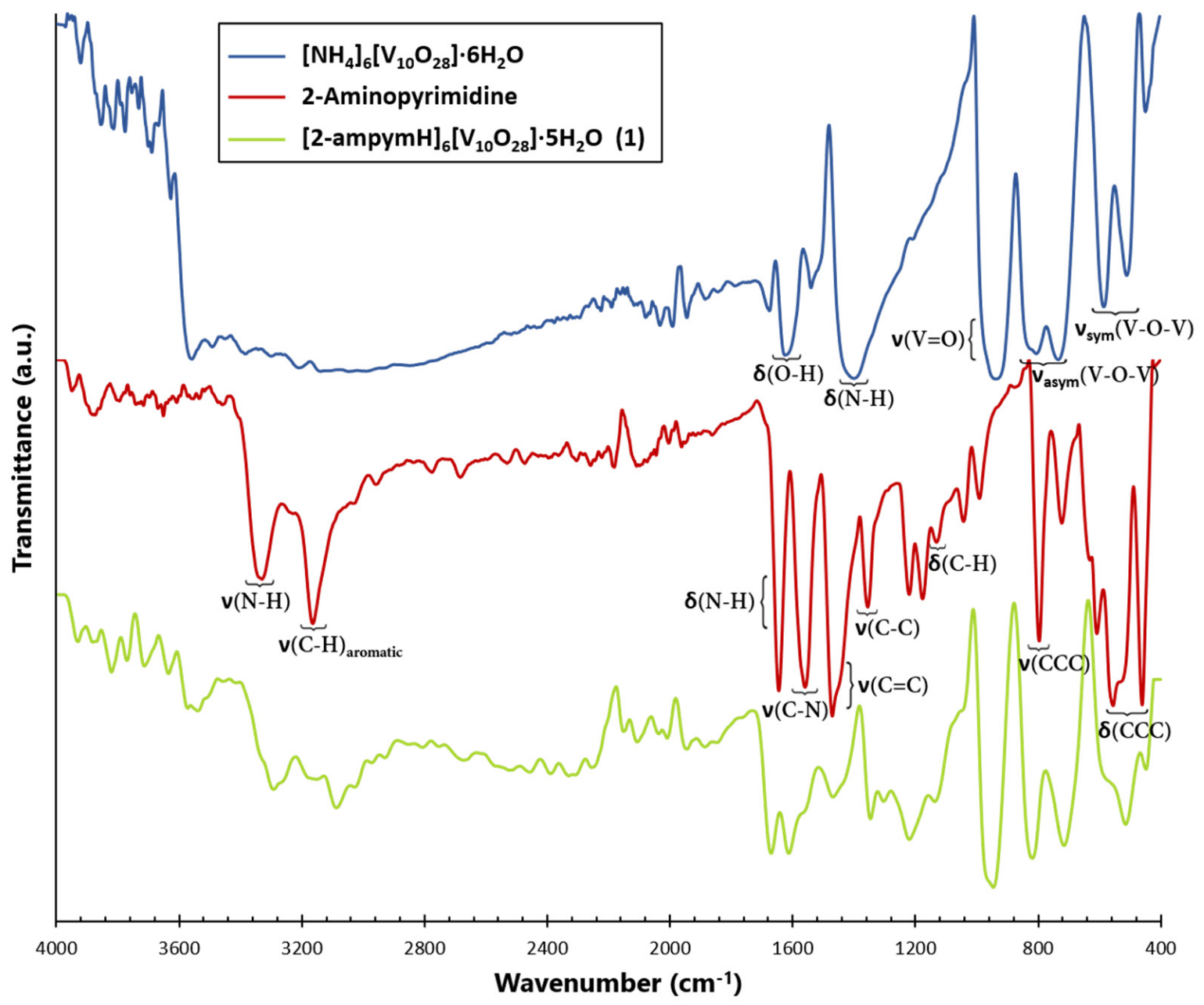

Figure 6. IR spectra of ammonium decavanadate, 2-aminopyrimidine ligand, and Compound 1 in the range $4000-400 \mathrm{~cm}^{-1}$ at room temperature.

Table 4. IR bands $\left(\mathrm{cm}^{-1}\right)$ of ammonium decavanadate, 2-aminopyrimidine ligand (2-ampym), and Compound 1 in the range of $4000-400 \mathrm{~cm}^{-1}$.

\begin{tabular}{cccc}
\hline Vibrational Mode & $\mathbf{( N H}_{\mathbf{4}} \mathbf{~}_{\mathbf{6}} \mathbf{V}_{\mathbf{1 0}} \mathbf{O}_{\mathbf{2 8}} \cdot \mathbf{6} \mathbf{H}_{\mathbf{2}} \mathbf{O}$ & 2-Ampym & Compound $\mathbf{1}$ \\
\hline$v(\mathrm{~N}-\mathrm{H})$ & - & 3331 & 3290 \\
$v(\mathrm{C}-\mathrm{H})_{\text {aromatic }}$ & - & 3165 & 3082 \\
$\delta(\mathrm{O}-\mathrm{H})$ & 1622 & - & - \\
$\delta(\mathrm{N}-\mathrm{H})$ & 1394 & 1645 & 1670 \\
$v(\mathrm{C}-\mathrm{N})$ & - & 1556 & 1610 \\
$v(\mathrm{C}=\mathrm{C})$ & - & 1469 & 1462 \\
$v(\mathrm{C}-\mathrm{C})$ & - & 1356 & 1346 \\
$\delta(\mathrm{C}-\mathrm{H})$ & - & 1128 & 1132 \\
$v(\mathrm{~V}=\mathrm{O})$ & 927 & - & 941 \\
$v_{\text {asym }}(\mathrm{V}-\mathrm{O}-\mathrm{V})$ & 825 & - & 814 \\
& 802 & & 711 \\
$v(\mathrm{CCC})$ & 731 & 794 & \\
$v_{\text {sym }}(\mathrm{V}-\mathrm{O}-\mathrm{V})$ & - & - & 580 \\
$\delta(\mathrm{C}-\mathrm{C}-\mathrm{C})$ & 580 & 555 & \\
& 505 & 459 & \\
\hline
\end{tabular}




\subsection{Thermal Study}

The thermal decomposition behavior of [2-ampymH $]_{6}\left[\mathrm{~V}_{10} \mathrm{O}_{28}\right] \cdot 5 \mathrm{H}_{2} \mathrm{O}(\mathbf{1})$ in solid-state was studied by TG analysis in the range of $35-950{ }^{\circ} \mathrm{C}$ (Figure S1). The thermogram of Compound 1 revealed a mass loss of around $5 \%$ in the range of $35-180^{\circ} \mathrm{C}$, which corresponded to five water molecules of crystallization (\% mass, calc. (found) for $5 \times \mathrm{H}_{2} \mathrm{O}: 5.5 \%(5.4 \%)$ ). Then, a continuous mass loss occurred in the range from 180 to $450{ }^{\circ} \mathrm{C}$, which may correspond to the thermal degradation of six 2-aminopyridinium cations (\% mass, calc. (found) for $6 \times \mathrm{C}_{4} \mathrm{H}_{6} \mathrm{~N}_{3}: 35.5 \%(36.3 \%)$ ). The total mass loss of Compound 1 was $41.85 \%$, which was in good agreement with the calculated value of $41 \%$. No further losses in mass were observed above $460{ }^{\circ} \mathrm{C}$, which can be attributed to the remaining $\left[\mathrm{V}_{10} \mathrm{O}_{28}\right]^{6-}$ fragment that may be thermally stable up to $600{ }^{\circ} \mathrm{C}$, as previously reported [50,51]. Nevertheless, some authors point out that further thermal treatment of decavanadate anion could result in the formation of other vanadium oxides, such as $\mathrm{V}_{2} \mathrm{O}_{5}$ or other mixed-valence oxides [52-54].

\subsection{Theoretical Calculations}

Figure 7 shows the molecular structure and isosurfaces of the Highest Occupied Molecular Orbital (HOMO) and Lowest Unoccupied Molecular Orbital (LUMO) molecular orbitals of Compound 1 plotted with an isovalue of $0.02 \mathrm{a}$.u. The frontier orbitals HOMO and LUMO can be related to donating or accepting electrons, respectively. The higher energy of the HOMO orbital indicates a more pronounced behavior as an electron donor, while the lower energy of the LUMO orbital indicates a higher electron affinity. The HOMO orbital, with energy of $-7.4671 \mathrm{eV}$, is located on the decavanadate anion, mainly on the Obridge atoms, as shown in Figure 7b, while the LUMO orbital, with energy of $-5.7381 \mathrm{eV}$, is located on the organic counterions of pyrimidine, mainly on the $\mathrm{C}$ and $\mathrm{N}$ atoms of the rings, as shown in Figure 7c.

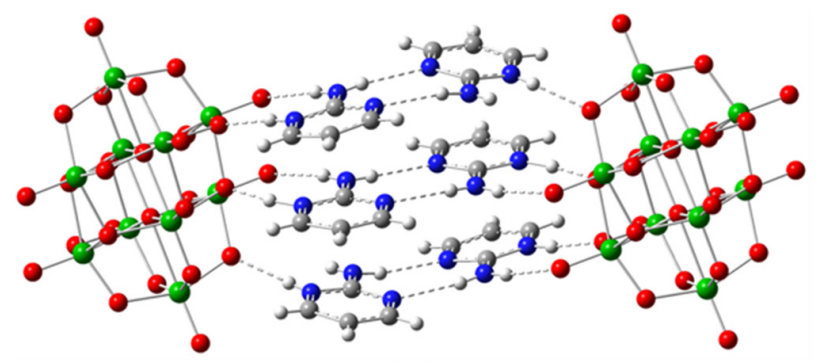

(a)

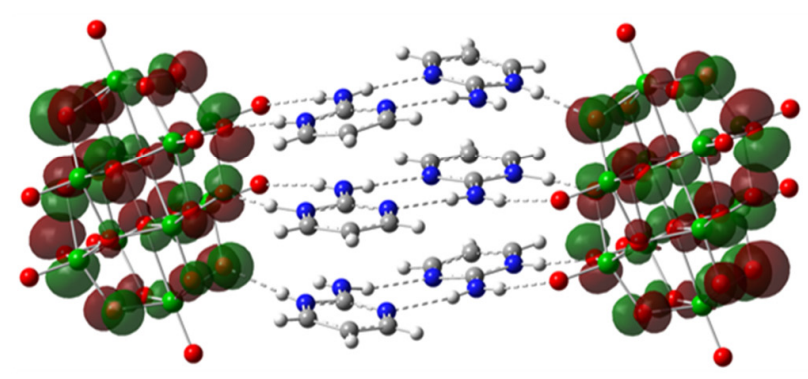

(b)

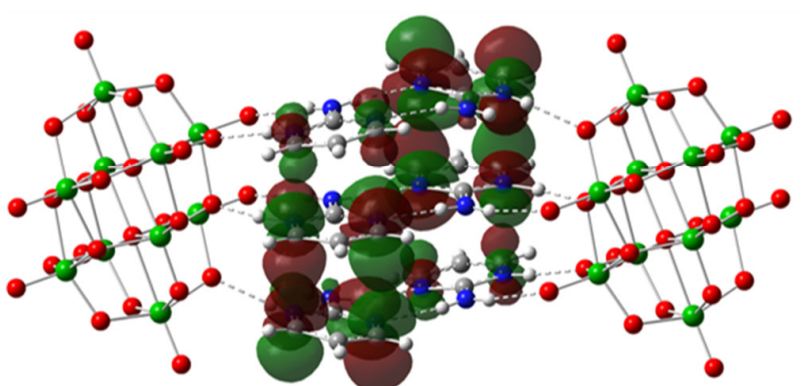

(c)

Figure 7. (a) Molecular structure, (b) HOMO isosurface, and (c) LUMO isosurface of Compound 1 calculated at the B3LYP/Def2SVP-LANL2DZ theory level using ECP = LANL2DZ for the V atom.

Figure 8 shows the molecular electrostatic potential (MEP) map of Compound 1 . The MEP map was mapped with an isovalue of $0.04 \times 10^{-2} \mathrm{a}$.u. in the range of $-3.45 \times 10^{-2}$ to $3.45 \times 10^{-2}$ and a.u. ${ }^{-3}$. The red zones indicate areas with high charge density (nucleophilic zone), while the blue zones indicate the presence of positive charge (electrophilic 
zones). It was observed that the areas with the highest charge density were located on the decavanadate anion, while the positively charged areas were located in the pyrimidine molecules. The non-covalent interactions between the $\mathrm{O}$ atoms of decavanadate anion and the $\mathrm{H}$ atoms of pyrimidine molecules were found in intermediate electron density zones, represented in yellow-green colors.

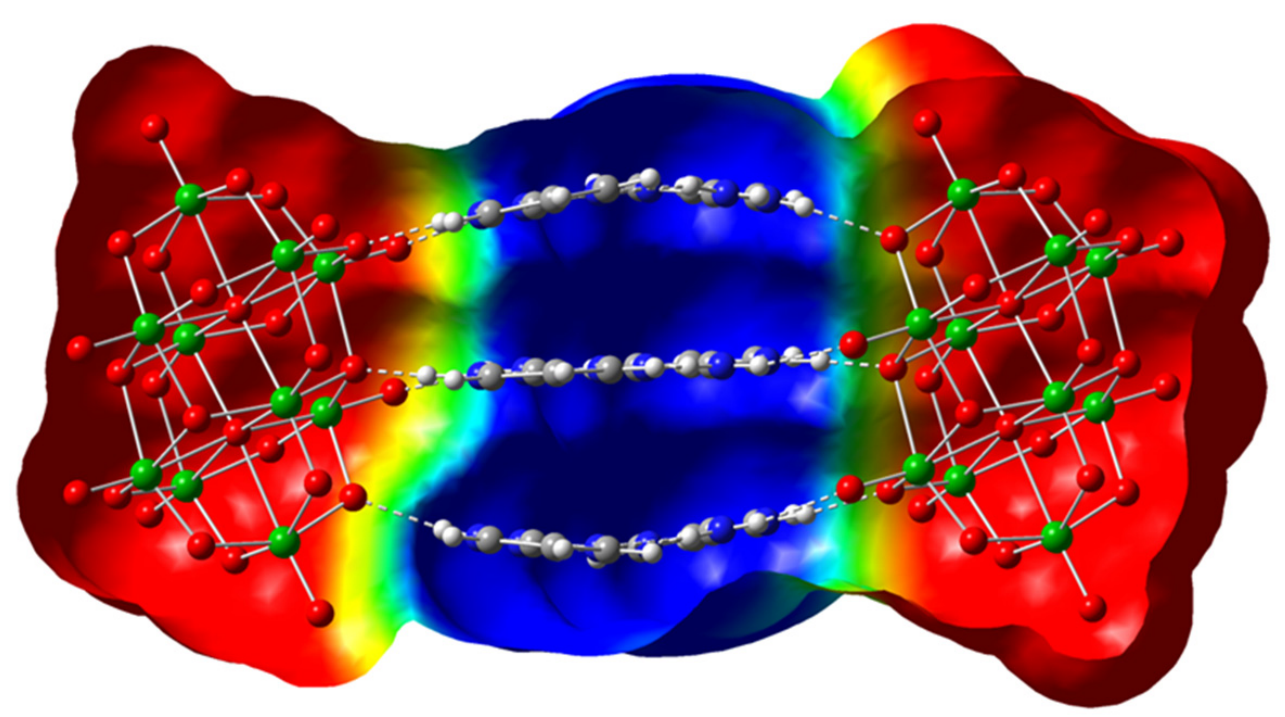

Figure 8. Molecular electrostatic potential map of Compound 1, calculated the theory level B3LYP/Def2SVP-LANL2DZ using ECP = LANL2DZ for the V atom. Vanadium atoms are represented in green. The red zones indicate areas with high charge density (nucleophilic zone), while the blue zones indicate the presence of positive charge (electrophilic zones).

The main non-covalent bonds between the decavanadate cluster and pyrimidine rings were characterized by topological electron density parameters, $\rho(r)$, the Laplacian of density, $\nabla^{2} \rho(r)$, the energy of interaction, $\mathrm{E}_{\mathrm{H} \cdots \mathrm{Y}}$, and the interatomic distance, $\mathrm{D}_{\text {int }}$. The results are shown in Table 5. In addition, Figure 9 shows the molecular graphs of Compound $\mathbf{1 .}$

Table 5. Topological parameters (in a.u.), interaction energies $\mathrm{E}_{\mathrm{H} \cdots \mathrm{Y}}\left(\mathrm{in} \mathrm{kcal} \mathrm{mol}^{-1}\right.$ ), and interatomic distances $D_{\text {int }}$ (in $\AA$ ).

\begin{tabular}{ccccc}
\hline BCP & $\boldsymbol{\rho}(\mathbf{r})$ & $\nabla^{\mathbf{2}} \boldsymbol{\rho}(\mathbf{r})$ & $\mathbf{E}_{\mathbf{H} \cdots \mathbf{Y}}$ & $\mathbf{D}_{\text {int }}$ \\
\hline O3 $\cdots$ H3AA & 0.0377 & 0.1440 & 11.26 & 1.8016 \\
O4 $\cdots$ H1AB & 0.0166 & 0.0636 & 4.51 & 2.1456 \\
O9 $\cdots$ H3BA & 0.0322 & 0.1345 & 9.88 & 1.8737 \\
O10 $\cdots$ H3CA & 0.0788 & 0.1830 & 23.02 & 1.4946 \\
O11 $\cdots$ H1CB & 0.0185 & 0.0705 & 5.11 & 2.0981 \\
N2A $\cdots$ H1BA & 0.0205 & 0.0684 & 4.80 & 2.1356 \\
N2B $\cdots$ H1AA & 0.0188 & 0.0691 & 4.54 & 2.1746 \\
N2C $\cdots$ H1CA & 0.0203 & 0.0758 & 5.05 & 2.9542 \\
\hline
\end{tabular}

From the results, it can be seen that the positive values of $\nabla^{2} \rho(r)$ indicates that non-covalent interactions are hydrogen bonds. The interaction energy is calculated using the equation $E_{H \cdots Y}=\frac{1}{2}|V(r)|$. The maximum value was found for the interaction $\mathrm{O} 10 \cdots \mathrm{H} 3 \mathrm{CA}$ with a value of 0.0788 a.u. and the highest interaction energy of $23.02 \mathrm{kcal} \mathrm{mol}^{-1}$. In addition, the interaction $\mathrm{O} 3 \cdots \mathrm{H} 3 \mathrm{AA}$ is strong with an energy of $11.26 \mathrm{kcal} \mathrm{mol}^{-1}$. The interaction energies between pyrimidine molecules are in the range of $4.54-5.05 \mathrm{kcal} \mathrm{mol}^{-1}$ (N2A $\cdots$ H1BA, N2B $\cdots$ H1AA, and N2C $\cdots$ H1CA). Figure 7a,b shows the $\pi-\pi$ stacking interactions between pyrimidine molecules. Many rings and 
cage critical points were also observed, which indicate the formation of a stable ring and cage-like structures that form between pyrimidine molecules and decavanadate, as well as between the central pyrimidine rings.

Lastly, the Hirshfeld surface of Compound 1, as shown in Figure 10a, was mapped with the normalized contact distance, $d_{\text {norm. }}$. It was observed that the red spots on the Hirshfeld surface were due to close intermolecular interactions of $\mathrm{O} \cdots \mathrm{H}$, between oxygen atoms of $\left[\mathrm{V}_{10} \mathrm{O}_{28}\right]^{6-}$ ion and hydrogen atoms of 2-aminopyrimidine. In Figure 10b, in the fingerprint plot, $\mathrm{d}_{\mathrm{i}}$ indicates the distance from the surface to the nearest nucleus inside the surface, and $d_{e}$ is the distance from the surface to the nearest nucleus outside the surface. The interaction $\mathrm{O} \cdots \mathrm{H}$ had the most significant contribution to the overall surface with $96.5 \%$, blue-green region of the surface. Other interactions with minor contributions were $\mathrm{O} \cdots \mathrm{N}(1.4 \%)$ and $\mathrm{O} \cdots \mathrm{O}(1.3 \%)$, which corresponded to the small grey zone of the whole surface.

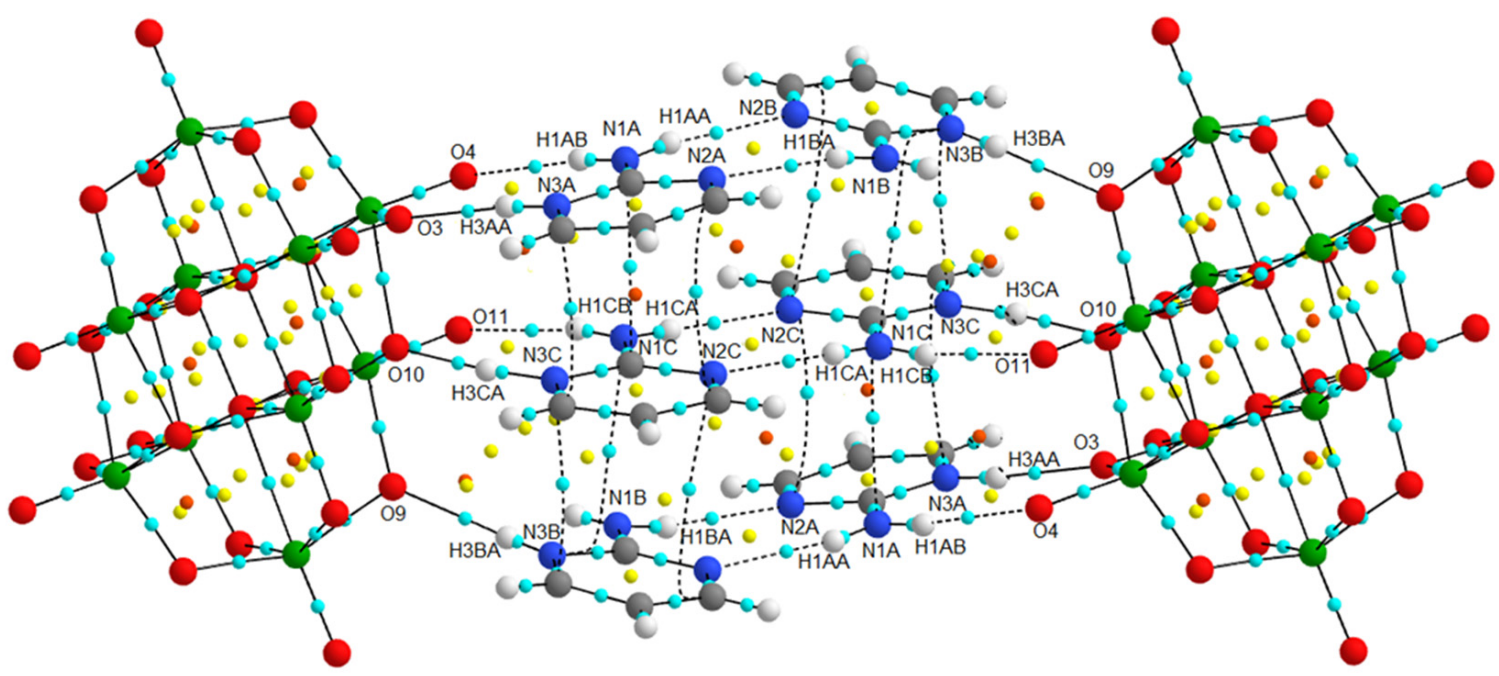

(a)

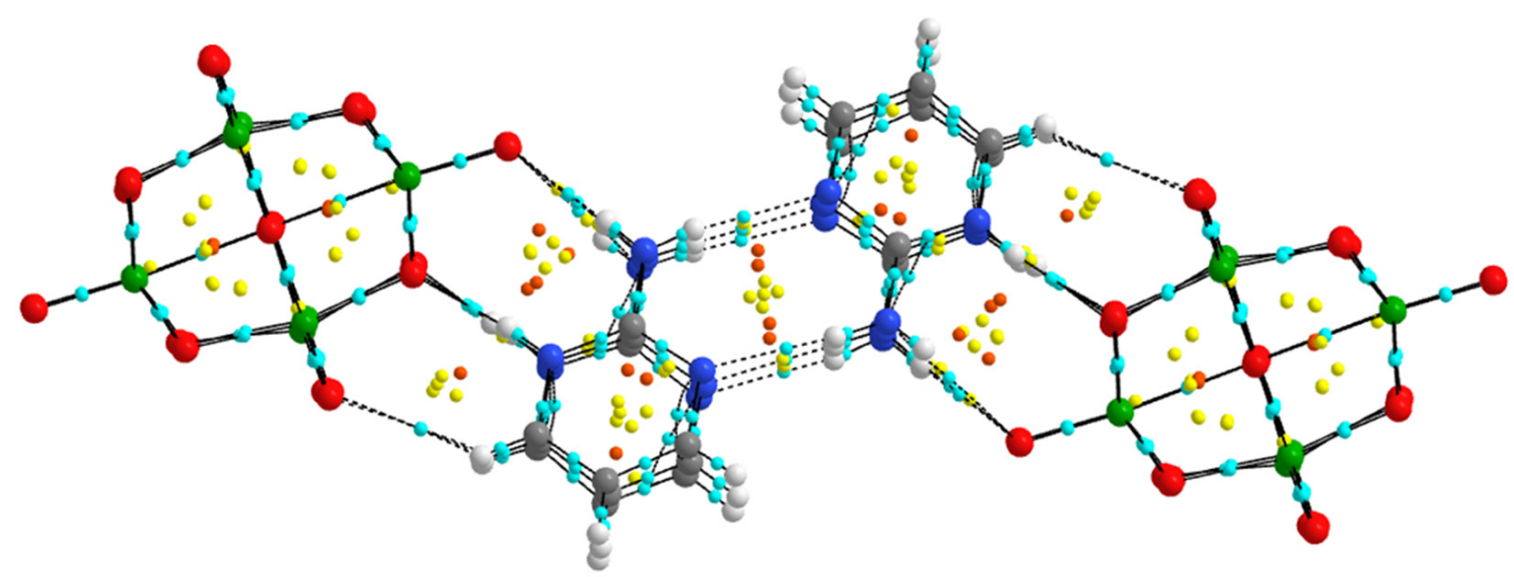

(b)

Figure 9. Molecular graphs of Compound 1: (a) showing the main H-bridge bonds between the decavanadate anion and pyrimidine molecules, (b) the interactions and the $\pi$-stacking arrangement between the pyrimidine rings as seen from a perpendicular orientation. Vanadium atoms are represented in green. Blue dots represent bond critical points (BCPs), yellow dots represent ring critical points (RCPs), and orange dots represent cage critical points (CCPs). 

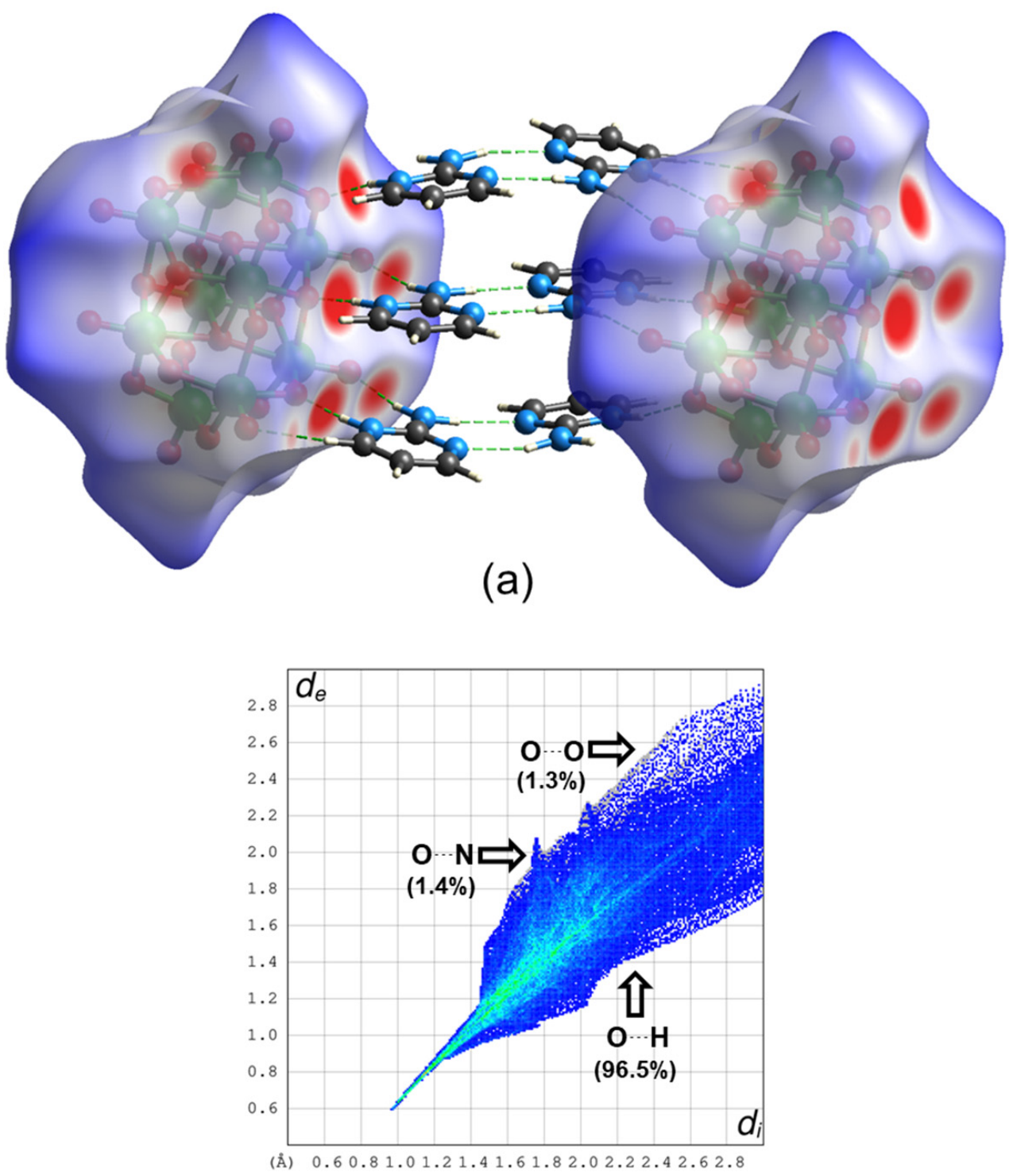

(b)

Figure 10. (a) Hirshfeld surface mapped with $d_{\text {norm }}$ parameter for Compound $\mathbf{1}$ and (b) fingerprint plot of non-covalent interactions. In (a) red spots represent close intermolecular interactions and green dash lines represent hydrogen bonds. In (b) blue-green region represent the contribution to the total area of the surface.

\subsection{Docking Analysis}

Molecular docking analysis was performed to test DNA/RNA interactions with Compound 1 using DNA and several microRNAs (miRNA), such as lncRNA, miR-21, and let-7 miRNA (Figure 11). The docked binding energies and interactions with the miRNAs structures were between -8.91 and $-8.39 \mathrm{Kcal} / \mathrm{mol}$ (Table 6). The interactions involve different positions between decavanadate and miRNAs that comprise hydrogen bonds and hydrophobic interactions mainly with the nitrogen bases Guanine and Adenine followed by Cytosine and Uracil (Figure 11a-c). 

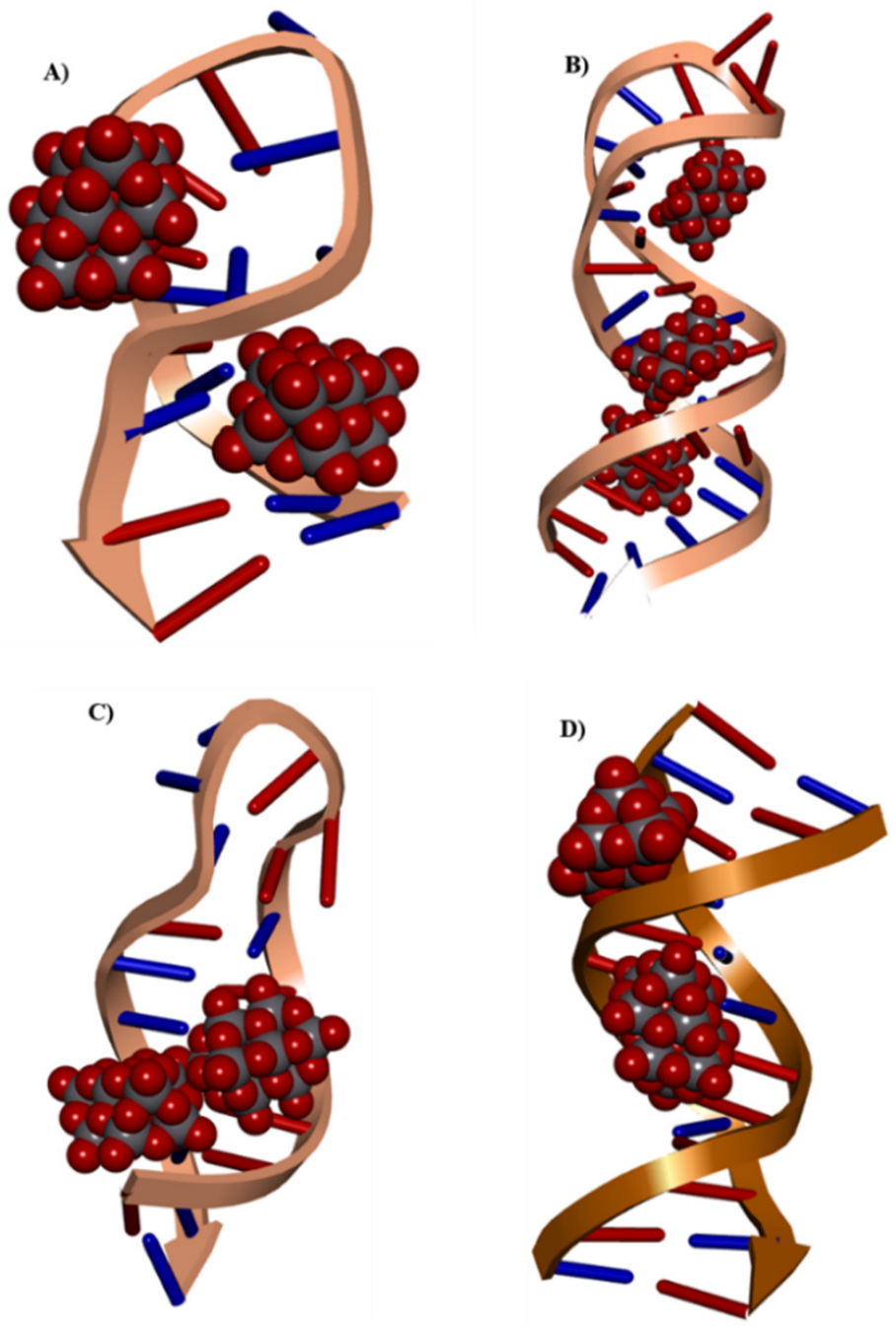

Figure 11. Docked structures of top molecular poses for: (A) decavanadate-pre-miRNA, (B) decavanadate-let-7 miRNA, (C) decavanadate-lncRNA, and (D) decavanadate-DNA. Vanadium atoms are represented as grey spheres. Red spheres represent oxygen atoms. Blue bars represent purine bases and red bars pyrimidine bases.

Table 6. Docking results. Binding energies for the decavanadate anion best molecular poses with miRNAs and DNA.

\begin{tabular}{lcccc}
\hline Compound & Target & $\begin{array}{c}\text { Binding Energies } \\
\text { (Kcal/mol) }\end{array}$ & H Bonds & Interactions \\
\hline & 2MNC (pre-miR-21) & -8.91 & 2 & C8, G10, C9, C21, A20 \\
& & -8.67 & 3 & G13, A14, C21, G13, A14, C17 \\
& 2JXV (let-7 miRNA) & -8.66 & 1 & G8, U24, U25, U9, C26, A716 \\
& & -8.58 & 5 & A3, G4, G5, U27, C29, C30 \\
Decavanadate & & -8.51 & 3 & A3, G1, G2, C17, U16 \\
& 6PK9 (lncRNA) & -8.48 & 1 & G4, G6, C15, G5 \\
\cline { 2 - 4 } & & -8.39 & 4 & G4, A5, G22, A6, C23 \\
& 1BNA (DNA) & -10.79 & 5 & A6, A17, A18, A5, G16 \\
\hline
\end{tabular}

The results obtained when docking was carried out considering DNA as a macromolecule showed binding energies of $-10.79 \mathrm{kcal} / \mathrm{mol}$ and the interaction involved hydrogen bonds with Guanine and Adenine (Figure 11d). 


\section{Discussion}

Every year, the global prevalence of cancer rises, as does the resistance to current chemotherapeutic agents like cisplatin; nowadays, one of the main goals of the pharmaceutical industry is the development of more effective drugs for the treatment of cancer [55,56].

This work presents a new structure based on the decavanadate cluster and the organic ligand, 2-aminopyrimidine. In general, pyrimidines are one of the most bioactive classes of compounds, with a wide range of biological activities, including in vitro antiviral, diuretic, antitumor, anti-HIV, and cardiovascular effects. Furthermore, pyrimidine moiety is present in the nucleobases that act as building blocks of nucleic acid, DNA or RNA, thymine, cytosine, and uracil, which might be one possible reason for the vast medicinal applications of pyrimidine-derived compounds [57]. Within the pyrimidines, the aminopyrimidine scaffold is present in the structure of a wide variety of natural and synthetic products, such as Thiamine (vitamin B1), Meridianins (a class of marine alkaloids), or Imatinib, a drug used against leukemia, which displays biological activities such as neuroprotection, antibiotic, antidiabetic, anti-Alzheimer, and anticancer. Among the large family of aminopyrimidines, the 2-aminopyrimidine isomer is the most studied, mainly because of its versatility as a starting material for synthesizing many other bioactive compounds [55].

Vanadium is an essential element, and it is important to keep the average vanadium concentration in the human body at around $0.3 \mu \mathrm{M}$ by supplementation via food and drinking water. In the organism, vanadium is found primarily in the form of vanadate $\mathrm{H}_{2} \mathrm{VO}_{4}{ }^{-}$that, due to the structural and chemical similarity with phosphate, is most likely involved in the regulation of phosphate-dependent processes, such as metabolic pathways involving phosphatases and kinases, as well as phosphate metabolism in general. In addition, organic ligands could aid in the modulation of vanadium's bioavailability, transport, and targeting mechanism, so, nowadays, coordination compounds containing vanadium are gaining in popularity because of their potential in the treatment of diabetes and cancer, leishmaniasis, and HIV [58]. In light of this, among vanadate compounds, some researchers have pointed out decavanadates as alternative antitumor agents with promising findings in tumor growth inhibition. Although the anticancer activity of decavanadate is more recent and not yet fully understood, it is probably due to the inhibition of different enzymes such as alkaline phosphatases, ectonucleotidases, and P-type ATPases [56]. One of the first articles published about decavanadate compounds with potential antitumor activity was $\mathrm{Na}_{4} \mathrm{Co}\left(\mathrm{H}_{2} \mathrm{O}\right)_{6} \mathrm{~V}_{10} \mathrm{O}_{28} \cdot 18 \mathrm{H}_{2} \mathrm{O}$ reported by Zhai et al. [15]. This compound in vitro displays higher inhibitory activity to human liver cancer (SMMC-7721) and ovary cancer (SK-OV-3) cell lines than 5-fluorouracil, the antitumoral drug clinically used, while in vivo, it can decrease liver tumor mass in rats. Shortly after, in 2010, Li et al. synthesized two decavanadates compounds with organic ligands that can inhibit proliferation of human lung (A549) and murine leukemia (P388) tumor cell lines in vitro: $\left(\mathrm{H}_{2} \text { tmen }\right)_{3} \mathrm{~V}_{10} \mathrm{O}_{28} \cdot 6 \mathrm{H}_{2} \mathrm{O}$ and $\left(\mathrm{H}_{2} \mathrm{en}\right)_{3} \mathrm{~V}_{10} \mathrm{O}_{28} \cdot 2 \mathrm{H}_{2} \mathrm{O}$ [27]. It is important to highlight that the first compound contains four methyl $\left(-\mathrm{CH}_{3}\right)$ substituents in the cation moiety. Their presence may enhance the lipophilic effect of this compound, which increases its penetration through the lipid bilayer of the cell membrane, thus showing higher inhibitory activity than the second compound. After that, a few more articles based on decavanadates compounds with potential antitumor activity have been published up to the present [29,53,59-61].

Since hydrogen bonds naturally occur between nucleobases and are of great biological importance for DNA and RNA structures, we chose the 2-aminopyrimidine molecule to obtain a new decavanadate compound with potential anticancer activity. Similar to this organic molecule, some structures with cytosine and decavanadate have been published. In the first compound published by Bošnjaković-Pavlović et al. [36], cytosine forms dimeric cytosine-cytosinium cations that stabilize the charge of the decavanadate anion. A few years later, the second material of decavanadate with cytosine in the literature was published [37]. In this compound, all cytosine (C) molecules are protonated, and the supramolecular structure is dominated by $\mathrm{C}-\mathrm{C}$ and $\mathrm{C}$-Decavanadate hydrogen bonds, as well as $\pi$-stacking interaction among heterocyclic rings with a centroid-to-centroid distance similar to that 
found in DNA and RNA structures. The fact that in both structures, cytosines interact with one another by hydrogen bonds and $\pi-\pi$ stacking similarly as in DNA and RNA polymers lead to two hypotheses: (i) polyoxidometalates could be employed as templates or catalysts for base-base linkages, and (ii) base-base pairing was crucial in the early stages of life [37]. Why nucleobases tend to form this arrangement in DNA and RNA has been studied by Francés-Monerris et al. [62]. The intra- and inter-strand interactions in Watson-Crick base pairs are of great importance for the thermal stability of the double-helix structure. In fact, in their experiments, upon UV light exposure at a B-DNA arrangement, C-C dimers twist towards a face-to-face arrangement to increase the $\pi$-stacking interaction and further promote the photostability of the genomic material. On the other hand, structures containing purine-based ligands show the same fact, as in the $\left(\mathrm{NH}_{4}\right)_{2}\left(\mathrm{C}_{8} \mathrm{H}_{10} \mathrm{~N}_{4} \mathrm{O}_{2}\right)_{4}\left[\mathrm{H}_{4} \mathrm{~V}_{10} \mathrm{O}_{28}\right] \cdot 2 \mathrm{H}_{2} \mathrm{O}$ compound, $\pi-\pi$ stacking interactions with an interplanar distance of $3.38 \AA$ exist in the purine rings of caffeine [63], and in $[\mathrm{AdH}]_{6}\left[\mathrm{~V}_{10} \mathrm{O}_{38}\right] \cdot 4 \mathrm{H}_{2} \mathrm{O}$, Adeninium cations form simultaneous hydrogen bond interactions in a ribbon-like geometry as well as $\pi-\pi$ interaction between cationic ribbons [6].

All these facts support the structure of Compound 1 in this paper, since 2-aminopyrimidinium cations are disposed of in the form that they interact with each other by hydrogen bonds and $\pi-\pi$ stacking interactions with a centroid-to centroid distance of around $3.6 \AA$.

Furthermore, to study the potential anticarcinogenic activity of Compound 1, docking tests were performed to analyze the interaction of the decavanadate anion with some types of microRNAs (miRNAs) and DNA molecules. MiRNAs are small, non-coding RNA molecules with a length of 19-25 nucleotides that regulate various target genes. MiRNAs play a role in the cell cycle, differentiation, proliferation, energy metabolism, and immunological response, among other biological activities, regulating around 30\% of human genes, with half of these genes being tumor-related. Recent studies have found that miRNAs play an important role in cancer progression, including tumor growth, differentiation, adhesion, apoptosis, invasion, and metastasis [64,65]. Within the miRNA family, the upregulations of miR-21, as well as lncRNA (long non-coding RNA), are linked to several types of cancer such as malignant B-cell lymphoma or breast cancer, respectively [66,67]. On the other hand, let-7 miRNA (member of the family of let-7 RNA) is known as the keeper of differentiation and has also emerged as a promising therapeutic agent to treat cancer and immune responses [68,69]. Thus, it is interesting to carry out experiments to prove this hypothesis, since our preliminary analyses show great affinity of decavanadate for miRNA fragments.

In addition to the possible antitumoral activity that Compound $\mathbf{1}$ could exhibit, the interesting structure that it shows, along with all the above examples about structures with decavanadate clusters and organic ligands that arrange remembering the DNA or RNA structures, highlights the idea that these polyoxidovanadates could act as templates or catalysts for base-base pairing. Bernal, in 1949, was the first who proposed the important role of clay minerals in the origin of life [70]. The advantage of these clays could include ordered arrangement, substantial adsorption capacity, UV protection, ability to concentrate organic compounds, and potential to serve as polymerization templates so that clay minerals could have played a key role in chemical evolution and the origin of life [71] Intercalation of decavanadate into laminar minerals has already been achieved [72], so it is possible to concentrate organic compounds with a high capacity for hydrogen bond formation and catalyze their polymerization. Therefore, it will be worthwhile to explore this idea.

Additionally, it is important to mention that recent work from Aureliano's group about melanoma anticancer activity of a variety of vanadium compounds [73] and potential antiSARS-CoV-2 activity of vanadium compounds by Scior et al. [74], present a promising future for vanadium compounds as metallodrugs. 


\section{Materials and Methods}

All starting reagents were purchased from Sigma-Aldrich (Merck, Naucalpan de Juarez, Mexico) and were used as received, without additional purification.

\subsection{Synthesis of [2-ampym $\mathrm{H}_{6}\left[\mathrm{~V}_{10} \mathrm{O}_{28}\right] \cdot 5 \mathrm{H}_{2} \mathrm{O}$ (1)}

A total of $0.4 \mathrm{mmol}(0.047 \mathrm{gr})$ of ammonium metavanadate $\left(\mathrm{NH}_{4} \mathrm{VO}_{3}\right)$, in situ precursor of decavanadate anion, was dissolved in $10 \mathrm{~mL}$ of distilled water at $80^{\circ} \mathrm{C}$ and stirred. After cooling to room temperature, the $\mathrm{pH}$ was lowered with a dissolution of concentrated $\mathrm{HCl}$ $(37 \%)$ to reach $\mathrm{pH}=3$. In a separate glass vessel, $0.2 \mathrm{mmol}(0.019 \mathrm{gr})$ of 2-aminopyrimidine ligand was dissolved in $4 \mathrm{~mL}$ of distilled water. This solution was gradually added to the orange solution of decavanadate, resulting in a $\mathrm{pH}$ close to 4.3 . The reaction mixture was then allowed to evaporate slowly at room temperature. After a week, orange crystals of Compound 1 for single-crystal $\mathrm{X}$-ray diffraction were obtained, filtered, and dried in air. Anal. Calcd. for $\mathrm{C}_{12} \mathrm{H}_{23} \mathrm{~N}_{9} \mathrm{O}_{16.5} \mathrm{~V}_{5}: \mathrm{C}, 17.75 ; \mathrm{H}, 2.85 ; \mathrm{N}, 15.52 \%$. Found: C, 16.83; H, 2.98; $\mathrm{N}, 14.91 \%$.

\subsection{Characterization Methods}

\subsubsection{Physicochemical Characterization}

Elemental analyses ( $\mathrm{C}, \mathrm{H}$, and $\mathrm{N}$ ) were carried out on a THERMO SCIENTIFIC analyzer model Flash 2000 (Thermo Fisher Scientific S.p.A., Milan, Italy), while thermal analyses were examined with a Shimadzu TGA-50H thermogravimetric analyzer (Shimadzu Corporation, Kyoto, Japan), with a heating rate of $10^{\circ} \mathrm{C} / \mathrm{min}$ under air atmosphere in the range of $35-950^{\circ} \mathrm{C}$, both of them at the "Centro de Instrumentación Científica" (University of Granada, Granada, Spain). The IR spectra of powdered samples were recorded in the $4000-400 \mathrm{~cm}^{-1}$ region with a BRUKER TENSOR 27 FT-IR, using the OPUS program as a data collector (Bruker Corporation, Billerica, MA, USA).

\subsubsection{Single-Crystal X-ray Diffraction}

X-ray quality orange crystals of Compound 1 were obtained.

The crystals were prepared under inert conditions immersed in perfluoropolyether as protecting oil for manipulation. Then, a suitable crystal was mounted on a MiTeGen Micromount $^{\mathrm{TM}}$ (MiTeGen, Ithaca, NY, USA) for data collection at 300(2) K. For Compound 1, diffraction intensities were collected with a Bruker D8 Venture diffractometer (Bruker Corporation, Billerica, MA, USA), using a photon detector equipped with graphite monochromated $M o K \alpha$ radiation $(\lambda=0.71073 \AA)$. Data reduction was performed with the APEX3 software [75] and corrected for absorption using SADABS [76]. The structure was solved by direct methods using the SHELXS-2013 program [77] and refined by full-matrix least-squares on $F^{2}$ with SHELXL-2018 [78]. The positional and anisotropic atomic displacement parameters were refined for all non-hydrogen atoms. Hydrogen atoms were located in difference Fourier maps and included as fixed contributions riding their parent atoms with isotropic thermal factors chosen as 1.2 times or 1.5 times those of their carrier atoms. One water molecule $(\mathrm{O} 2 \mathrm{~W})$ is disordered into two dispositions, so it was refined with occupancy of $50 \%$ and anisotropic displacement parameters. OLEX2 software [79] was used as a graphical interface. The Addsym routine implemented in the program PLATON [80] supported a $P \overline{1}$ symmetry. Crystallographic data (excluding structure factors) for the structure reported in this paper have been deposited with the Cambridge Crystallographic Data Centre as supplementary publication no. 2099300 for Compound 1. Copies of the data can be obtained free of charge on application to the Director, CCDC, 12 Union Road, Cambridge, CB2 1EZ, U.K. (Fax: +44-1223-335033; e-mail: deposi@@ccdc.cam.ac.uk or http:/ / www.ccdc.cam.ac.uk, accessed on 15 August 2021).

\subsubsection{Theoretical Methodology}

The structural and electronic structure of Compound 1 were calculated using the density functional theory, DFT [81]. The hybrid functional B3LYP [82] was used, using 
the Def2SVP basis set [83] for the atoms of C, H, O, and N; and LANL2DZ [84] for vanadium atom with an effective core potential (ECP). The frontier molecular orbitals (highest occupied molecular orbital, HOMO, and lowest unoccupied molecular orbital, LUMO) and the molecular electrostatic potential (MEP) map were analyzed. The calculations were performed with the Gaussian program16 [85], and the visualization of the results was performed with the Gaussian View 6.0.16 program [86]. Additionally, the main non-covalent interactions in Compound 1 were characterized using the atoms in molecules (AIM) approach with AIMAll software [87] and Hirshfeld surface analysis with CrystalExplorer 17.5 software [88].

\subsubsection{Docking Analysis}

Molecular docking analysis was performed with the semi-flexible methodology, where the RNAs fragments were considered as a rigid entity, while flexibility was allowed for the decavanadate. The preparation of the macromolecule and the ligand was performed through the Autodock Tools 1.5 .6 software [89], which includes polar hydrogens and empirical particles of atomic charges (Gasteiger-Marsili method). Different grid box sizes were used for each RNA molecule that encloses the entire fragment: for 6PK9, 60, 106, and $60 \AA$ were used; 70, 126, and $70 \AA$ for 2JXV fragment; and 94, 76, and $66 \AA$ were used for $2 \mathrm{MNC}$. In addition to those fragments, one DNA structure was considered in the docking study: 1BNA, with sizes of 70, 70, and $120 \AA$. The grid spacing for all the docking calculations was set to the default $0.375 \AA$ value, using the Lamarckian genetic algorithm (LGA) searching methods. The parameters for the vanadium atom were the sum of VDW radii of two similar atoms $(3.14 \AA)$, plus the VDW well depth $(0.016 \mathrm{kcal} / \mathrm{mol})$, plus the atomic solvation volume $\left(12.0 \AA^{3}\right)$, plus the atomic solvation parameter $(-0.00110)$. The $\mathrm{H}$-bond radius of the heteroatom in contact with hydrogen $(0.0 \AA)$, the well depth of the $\mathrm{H}$-bond $(0.0 \mathrm{kcal} / \mathrm{mol})$ and different integers indicate the type of H-bonding atom and indexes for the generation of the autogrid map $(0,-1,-1,1$, respectively).

\section{Conclusions}

A new decavanadate compound containing 2-aminopyrimidine was synthesized and characterized experimentally through elemental analysis, infrared spectroscopy, thermogravimetric analyses, and single-crystal X-ray diffraction. Using theoretical studies based on DFT calculations and AIM, the non-covalent interactions present in the compound were also studied. Frontier molecular orbital, molecular electrostatic potential, and non-covalent interactions were completely characterized. The hydrogen bond patterns of this molecule, although similar to the already reported Adenine-decavanadate compound, has the interesting feature of resembling the ladder-like structure of DNA and RNA molecules, even with similar distances from the centroid-to-centroid and $\pi-\pi$ interactions, it also occurs in triads, which could remind codon an anticodon interactions. A docking study was set to explore more of the resemblance with DNA and RNA to see the possibility of decavanadate interacting with RNA molecules. Thus, a set of test miRNA was considered for docking. The latest development in understanding the roles of non-coding RNAs and microRNAs is worthwhile to try some fitting. Although the negative charge of these molecules could prevent interactions with the anionic decavanadate, the formation of several hydrogen bonds with the nucleobases appears to counteract the charge problem, and relatively good interaction energies were observed. At the moment, this only suggests that experiments should be designed to test whether these interactions are worthwhile to pursue. The catalytic properties to build blocks with the correct orientation and similar types of interactions could also be explored since it could shed some light on the nature of the first replicator. On the other hand, since cancer cells exhibit increased levels of mRNA translation to meet tumor growth requirements [90], it will be interesting to explore the interactions of polyoxidovanadates with mRNA. Therefore, new and fascinating decavanadate chemistry is around the corner. 
Supplementary Materials: The following are available online at https: / www.mdpi.com/article/ 10.3390/inorganics9090067/s1, Table S1: Fractional Atomic Coordinates $\left(\times 10^{4}\right)$ and Equivalent Isotropic Displacement Parameters $\left(\AA^{2} \times 10^{3}\right)$ for Compound 1. $U_{\text {eq }}$ is defined as $1 / 3$ of the trace of the orthogonalized $U_{\text {IJ }}$ tensor, Table S2: Anisotropic Displacement Parameters $\left(\AA^{2} \times 10^{3}\right)$ for Compound 1. The Anisotropic displacement factor exponent takes the form: $-2 \pi^{2}\left[h^{2} a^{* 2} U_{11}+\right.$ $2 \mathrm{hka}{ }^{*} \mathrm{~b}^{*} \mathrm{U}_{12}+\ldots$ ], Table S3: Bond Lengths for Compound 1, Table S4: Bond Angles for Compound 1, Table S5: Torsion Angles for Compound 1, Table S6: Hydrogen Atom Coordinates $\left(\AA \times 10^{4}\right)$ and Isotropic Displacement Parameters $\left(\AA^{2} \times 10^{3}\right)$ for Compound 1, Table S7: Atomic Occupancy for Compound 1, Figure S1: TG spectrum of Compound $\mathbf{1}$ in the range of $35-950{ }^{\circ} \mathrm{C}$.

Author Contributions: A.G.-G. carried out experimental work (synthesis, crystallization, and experimental characterization). F.J.M.-B., M.E.C. and L.N. carried out the theoretical characterization. A.G.-G., D.C.-L. and A.R.-D. carried out the X-ray diffraction determination. A.G.-G., E.G.-V., M.E.C. and B.L.S.-G., wrote and revised the manuscript. E.G.-V. and A.R.-D. conceived and designed this study. All authors contributed extensively to the work presented in this paper. All authors have read and agreed to the published version of the manuscript.

Funding: Projects that funded this research: 100517029-VIEP, 100233622-VIEP, SEP PRODEP BUAPPTC_617, and PRODEP Academic Group BUAP-CA-263 (SEP, Mexico). Financial support was also provided by Junta de Andalucía (Spain), project number FQM-394.

Acknowledgments: M.E.C. and F.J.M.-B. wish to thank Laboratorio Nacional de Supercómputo del Sureste de México (LNS-BUAP) and the CONACyT network of national laboratories for the computer resources and provided support. B.L.S.-G. thanks for the grant SEP PRODEP BUAP-PTC_617. We thank the support provided by VIEP-BUAP through Yadira Rosas Bravo for observations and comments to improve this manuscript.

Conflicts of Interest: There are no conflict of interest to declare.

\section{References}

1. Proust, A.; Thouvenot, R.; Gouzerh, P. Functionalization of polyoxidometalates: Towards advanced applications in catalysis and materials science. Chem. Commun. 2008, 16, 1837-1852. [CrossRef]

2. Bijelic, A.; Aureliano, M.; Rompel, A. Polyoxidometalates as Potential Next-Generation Metallodrugs in the Combat against Cancer. Angew. Chem. Int. Ed. 2019, 58, 2980-2999. [CrossRef]

3. Bijelic, A.; Aureliano, M.; Rompel, A. The antibacterial activity of polyoxidometalates: Structures, antibiotic effects and future perspectives. Chem. Commun. 2018, 54, 1153-1169. [CrossRef]

4. Evans, H.T. The Molecular Structure of the Isopoly Complex Ion, Decavanadate $\left(\mathrm{V}_{10} \mathrm{O}_{28}{ }^{6-}\right)$. Inorg. Chem. 1966, 5, 967-977. [CrossRef]

5. Gumerova, N.I.; Rompel, A. Polyoxometalates in solution: Speciation under spotlight. Chem. Soc. Rev. 2020, 49, 7568-7601. [CrossRef]

6. Sedghiniya, S.; Soleimannejad, J.; Jahani, Z.; Davoodi, J.; Janczak, J. Crystal engineering of an adenine-decavanadate molecular device towards label-free chemical sensing and biological screening. Acta Cryst. 2020, B76, 85-92. [CrossRef] [PubMed]

7. Hartung, S.; Bucher, N.; Chen, H.-Y.; Al-Oweini, R.; Sreejith, S.; Borah, P.; Yanli, Z.; Kortz, U.; Stimming, U.; Hoster, H.E.; et al. Vanadium-based polyoxidometalate as new material for sodium-ion battery anodes. J. Power Sources 2015, 288, 270-277. [CrossRef]

8. Xie, A.; Ma, C.-A.; Wang, L.; Chu, Y. $\mathrm{Li}_{6} \mathrm{~V}_{10} \mathrm{O}_{28}$, a novel cathode material for Li-ion battery. Electrochim. Acta 2007, 52, 2945-2949. [CrossRef]

9. Ji, Y.; Liu-Théato, X.; Xiu, Y.; Indris, S.; Njel, C.; Maibach, J.; Ehrenberg, H.; Fichtner, M.; Zhao-Karger, Z. Polyoxidometalate Modified Separator for Performance Enhancement of Magnesium-Sulfur Batteries. Adv. Funct. Mater. 2021, 2100868, 1-7.

10. Steens, N.; Ramadan, A.M.; Absillis, G.; Parac-Vogt, T.N. Hydrolytic cleavage of DNA-model substrates promoted by polyoxidovanadates. Dalton Trans. 2010, 39, 585-592. [CrossRef]

11. Wang, C.; Chen, Z.; Yao, X.; Chao, Y.; Xun, S.; Xiong, J.; Fan, L.; Zhu, W.; Li, H. Decavanadates anchored into micropores of graphene-like boron nitride: Efficient heterogeneous catalysts for aerobic oxidative desulfurization. Fuel 2018, 230, 104-112. [CrossRef]

12. Huang, X.; Gu, X.; Zhang, H.; Shen, G.; Gong, S.; Yang, B.; Wang, Y.; Chen, Y. Decavanadate-based clusters as bifunctional catalysts for efficient treatment of carbon dioxide and simulant sulfur mustard. J. CO2 Util. 2021, 45, 101419. [CrossRef]

13. Diaz, A.; Muñoz-Arenas, G.; Venegas, B.; Vázquez-Roque, R.; Flores, G.; Guevara, J.; Gonzalez-Vergara, E.; Treviño, S. Metforminium decavanadate (MetfDeca) Treatment Ameliorates Hippocampal Neurodegeneration and Recognition Memory in a Metabolic Syndrome Model. Neurochem. Res. 2021, 46, 1151-1165. [CrossRef] 
14. Pereira, M.J.; Carvalho, E.; Eriksson, J.W.; Crans, D.C.; Aureliano, M. Effects of decavanadate and insulin enhancing vanadium compounds on glucose uptake in isolated rat adipocytes. J. Inorg. Biochem. 2009, 103, 1687-1692. [CrossRef] [PubMed]

15. Zhai, F.; Wang, X.; Li, D.; Zhang, H.; Li, R.; Song, L. Synthesis and biological evaluation of decavanadate $\mathrm{Na}_{4} \mathrm{Co}\left(\mathrm{H}_{2} \mathrm{O}\right)_{6} \mathrm{~V}_{10} \mathrm{O}_{28} \cdot 18 \mathrm{H}_{2} \mathrm{O}$. Biomed. Pharmacother. 2009, 63, 51-55. [CrossRef] [PubMed]

16. Aureliano, M.; Gumerova, N.I.; Sciortino, G.; Garribba, E.; Rompel, A.; Crans, D.C. Polyoxovanadates with emerging biomedical activities. Coord. Chem. Rev. 2021, 447, 214143. [CrossRef]

17. Cantley, L.C.; Josephson, L.; Warner, R.; Yanagisawa, M.; Lechene, C.; Guidotti, G. Vanadate Is a Potent (Na, K)-ATPase Inhibitor Found in ATP Derived from Muscle. J. Biol. Chem. 1977, 252, 7421-7423. [CrossRef]

18. Aureliano, M.; Crans, D.C. Decavanadate $\left(\mathrm{V}_{10} \mathrm{O}_{28}{ }^{6-}\right)$ and oxovanadates: Oxometalates with many biological activities. J. Inorg. Biochem. 2009, 103, 536-546. [CrossRef]

19. Aureliano, M. Decavanadate: A journey in a search of a role. Dalton Trans. 2009, 42, 9093-9100. [CrossRef]

20. García-Vicente, S.; Yraola, F.; Marti, L.; González-Muñoz, E.; García-Barrado, M.J.; Cantó, C.; Abella, A.; Bour, S.; Artuch, R.; Sierra, C.; et al. Oral Insulin-Mimetic Compounds That Act Independently of Insulin. Diabetes 2007, 56, 486-493. [CrossRef]

21. Treviño, S.; Sánchez-Lara, E.; Sarmiento-Ortega, V.E.; Sánchez-Lombardo, I.; Flores-Hernández, J.Á.; Pérez-Benítez, A.; BrambilaColombres, E.; González-Vergara, E. Hypoglycemic, lipid-lowering and metabolic regulation activities of metforminium decavanadate $\left(\mathrm{H}_{2} \text { Metf }\right)_{3}\left[\mathrm{~V}_{10} \mathrm{O}_{28}\right] \cdot 8 \mathrm{H}_{2} \mathrm{O}$ using hypercaloric-induced carbohydrate and lipid deregulation in Wistar rats as biological model. J. Inorg. Biochem. 2015, 147, 85-92. [CrossRef]

22. Treviño, S.; Díaz, A.; Sánchez-Lara, E.; Sarmiento-Ortega, V.E.; Flores-Hernández, J.Á.; Brambila, E.; Meléndez, F.J.; GonzálezVergara, E. Pharmacological and Toxicological Threshold of Bisammonium Tetrakis 4-(N,N-Dimethylamino)pyridinium Decavanadate in a Rat Model of Metabolic Syndrome and Insulin Resistance. Bioinorg. Chem. Appl. 2018, 2151079, 1-13. [CrossRef]

23. Turner, T.L.; Nguyen, V.H.; McLauchlan, C.C.; Dymon, Z.; Dorsey, B.M.; Hooker, J.D.; Jones, M.A. Inhibitory effects of decavanadate on several enzymes and Leishmania tarentolae In Vitro. J. Inorg. Biochem. 2012, 108, 96-104. [CrossRef] [PubMed]

24. Missina, J.M.; Gavinho, B.; Postal, K.; Santana, F.S.; Valdameri, G.; de Souza, E.M.; Hughes, D.L.; Ramirez, M.I.; Soares, J.F.; Nunes, G.G. Effects of Decavanadate Salts with Organic and Inorganic Cations on Escherichia coli, Giardia intestinalis, and Vero Cells. Inorg. Chem. 2018, 57, 11930-11941. [CrossRef]

25. Samart, N.; Arhouma, Z.; Kumar, S.; Murakami, H.A.; Crick, D.C.; Crans, D.C. Decavanadate Inhibits Mycobacterial Growth More Potently Than Other Oxovanadates. Front. Chem. 2018, 6, 519. [CrossRef]

26. Marques-da-Silva, D.; Fraqueza, G.; Lagoa, R.; Vannathan, A.A.; Mal, S.S.; Aureliano, M. Polyoxidovanadate inhibition of Escherichia coli growth shows a reverse correlation with $\mathrm{Ca}^{2+}$-ATPase inhibition. New. J. Chem. 2019, 43, 17577-17587. [CrossRef]

27. Li, Y.-T.; Zhu, C.-Y.; Wu, Z.-Y.; Jiang, M.; Yan, C.-W. Synthesis, crystal structures and anticancer activities of two decavanadate compounds. Transit. Met. Chem. 2010, 35, 597-603. [CrossRef]

28. Silva-Nolasco, A.M.; Camacho, L.; Saavedra-Díaz, R.O.; Hernández-Abreu, O.; León, I.E.; Sánchez-Lombardo, I. Kinetic Studies of Sodium and Metforminium Decavanadates Decomposition and In Vitro Cytotoxicity and Insulin-Like Activity. Inorganics 2020, 8, 67. [CrossRef]

29. Louati, M.; Ksiksi, R.; Elbini-Dhouib, I.; Mlayah-Bellalouna, S.; Doghri, R.; Srairi-Abid, N.; Zid, M.-F. Synthesis, structure, and characterization of a novel decavanadate, $\mathrm{Mg}\left(\mathrm{H}_{2} \mathrm{O}\right)_{6}\left(\mathrm{C}_{4} \mathrm{~N}_{2} \mathrm{H}_{7}\right)_{4} \mathrm{~V}_{10} \mathrm{O}_{28} \cdot 4 \mathrm{H}_{2} \mathrm{O}$, with a potential antitumor activity. J. Mol. Struct. 2021, 1242, 130711. [CrossRef]

30. Sánchez-Lara, E.; Martínez-Valencia, B.; Corona-Motolinia, N.D.; Sanchez-Gaytan, B.L.; Castro, M.E.; Bernès, S.; Méndez-Rojas, M.A.; Meléndez-Bustamante, F.J.; González-Vergara, E. A one-dimensional supramolecular chain based on $\left[\mathrm{H}_{2} \mathrm{~V}_{10} \mathrm{O}_{28}\right]^{4-}$ units decorated with 4-dimethylaminopyridinium ions: An experimental and theoretical characterization. New J. Chem. 2019, 43, 17746-17755. [CrossRef]

31. Bosnjakovic-Pavlovic, N.; Spasojevic-De-Biré, A. Cytosine-Cytosinium Dimer Behavior in a Cocrystal with a Decavanadate Anion as a Function of the Temperature. J. Phys. Chem. A. 2010, 114, 10664-10675. [CrossRef]

32. Sánchez-Lara, E.; Treviño, S.; Sánchez-Gaytán, B.L.; Sánchez-Mora, E.; Castro, M.E.; Meléndez-Bustamante, F.J.; Méndez-Rojas, M.A.; González-Vergara, E. Decavanadate Salts of Cytosine and Metformin: A Combined Experimental-Theoretical Study of Potential Metallodrugs Against Diabetes and Cancer. Front. Chem. 2018, 6, 1-18. [CrossRef] [PubMed]

33. Cui, C.; Liu, S.; Zhao, W. The crystal structure of hexakis(2-(pyridin-2-ylamino)pyridin-1-ium) decavanadate(V) dihydrate, $\mathrm{C}_{60} \mathrm{H}_{64} \mathrm{~N}_{18} \mathrm{O}_{30} \mathrm{~V}_{10}$. Z. Kristallogr. NCS 2021, 236, 25-27. [CrossRef]

34. Zarroug, R.; Abdallah, A.H.; Guionneau, P.; Masip-Sánchez, A.; López, X.; Ayed, B. Decavanadate salts of piperidine and triethanolamine: A combined experimental and theoretical study. J. Mol. Struct. 2021, 1241, 130677. [CrossRef]

35. Sgambellone, M.A.; David, A.; Garner, R.N.; Dunbar, K.R.; Turro, C. Cellular Toxicity Induced by the Photorelease of a Caged Bioactive Molecule: Design of a Potential Dual-Action Ru(II) Complex. J. Am. Chem. Soc. 2013, 135, 11274-11282. [CrossRef]

36. Amr, A.-G.E.; Mohamed, A.M.; Mohamed, S.F.; Abdel-Hafez, N.A.; Hammam, A.E.-F.G. Anticancer activities of some newly synthesized pyridine, pyrane, and pyrimidine derivatives. Bioorg. Med. Chem. 2006, 14, 5481-5488. [CrossRef] [PubMed]

37. Eicher, T.; Hauptmann, S.; Speicher, A. The Chemistry of Heterocycles: Structure, Reactions, Syntheses, and Applications, 2nd ed.; Wiley-VCH: Weinheim, Germany, 2003; pp. 269-310, 398-408.

38. Sciortino, G.; Aureliano, M.; Garribba, E. Rationalizing the Decavanadate(V) and Oxidovanadium(IV) Binding to G-Actin and the Competition with Decaniobate(V) and ATP. Inorg. Chem. 2021, 60, 334-344. [CrossRef] [PubMed] 
39. Jin, K.P.; Jiang, H.J.; Wang, Y.; Zhang, D.P.; Mei, J.; Cui, S.H. Synthesis and Crystal Structure of Decavanadate-Based Coordination Polymers. J. Cluster Sci. 2018, 29, 785-792. [CrossRef]

40. Scheinbeim, J.; Schempp, E. 2-Aminopyrimidine. Acta Cryst. 1976, B32, 607-609. [CrossRef]

41. Correia, I.; Avecilla, F.; Marcao, S.; Pessoa, J.C. Structural studies of decavanadate compounds with organic molecules and inorganic ions in their crystal packing. Inorg. Chim. Acta 2004, 357, 4476-4487. [CrossRef]

42. Aissa, T.; Ksiksi, R.; Elbini-Dhouib, I.; Doghri, R.; Srairi-Abid, N.; Zid, M.F. Synthesis of a new vanadium complex (V), hexa[4methylimidazolium]decavanadate trihydrate $\left(\mathrm{C}_{4} \mathrm{H}_{7} \mathrm{~N}_{2}\right)_{6} \mathrm{~V}_{10} \mathrm{O}_{28} \cdot 3 \mathrm{H}_{2} \mathrm{O}$ : Physico-chemical and biological characterizations. J. Mol. Struct. 2021, 1236, 130331. [CrossRef]

43. Mahmoud, G.A.-E.; Ibrahim, A.B.M.; Mayer, P. $\left(\mathrm{NH}_{4}\right)_{2}\left[\mathrm{Ni}\left(\mathrm{H}_{2} \mathrm{O}\right)_{6}\right]_{2} \mathrm{~V}_{10} \mathrm{O}_{28} \cdot 4 \mathrm{H}_{2} \mathrm{O}$; Structural Analysis and Bactericidal Activity against Pathogenic Gram-Negative Bacteria. ChemistrySelect 2021, 6, 3782-3787. [CrossRef]

44. Hou, W.; Guo, J.; Wang, Z.; Xu, Y. Synthesis, structural characterization, and properties of two new polyoxidovanadates based on decavanadate $\left[\mathrm{V}_{10} \mathrm{O}_{28}\right]^{6-}$. J. Coord. Chem. 2013, 66, 2434-2443. [CrossRef]

45. Etter, M.C.; MacDonald, J.C. Graph-Set Analysis of Hydrogen-Bond Patterns in Organic Crystals. Acta Cryst. 1990, B46, 256-262. [CrossRef]

46. Janiak, C. A critical account on $\pi-\pi$ stacking in metal complexes with aromatic nitrogen-containing ligands. J. Chem. Soc. Dalton Trans. 2000, 21, 3885-3896. [CrossRef]

47. Chen, J.; Dai, L.; Li, J.; Mohammadnia, M. Pd based on 2-Aminopyrimidine and $1 H$-benzo[d]imidazol-2-amine functionalized $\mathrm{Fe}_{3} \mathrm{O}_{4}$ nanoparticles as novel recyclable magnetic nanocatalysts for Ullmann coupling reaction. Appl. Organomet. Chem. 2020, 34, e5708. [CrossRef]

48. Gupta, P.K.; Arora, K. Studies on Simulation of Spectra of some Organic Compounds. Orient. J. Chem. 2019, 35, 1655-1668. [CrossRef]

49. Thangarasu, S.; Athimoolam, S.; Bahadur, S.A.; Manikandan, A. Structural, Spectroscopic Investigation and Computational Study on Nitrate and Hydrogen Oxalate Salts of 2-Aminopyrimidine. J. Nanosci. Nanotechnol. 2018, 18, 2450-2462. [CrossRef]

50. Ortaboy, S.; Acar, E.T.; Atun, G. The removal of radioactive strontium ions from aqueous solutions by isotopic exchange using strontium decavanadates and corresponding mixed oxides. Chem. Eng. J. 2018, 344, 194-205. [CrossRef]

51. Omri, I.; Mhiri, T.; Graia, M. Novel decavanadate cluster complex $(\mathrm{HImz})_{12}\left(\mathrm{~V}_{10} \mathrm{O}_{28}\right)_{2} \cdot 3 \mathrm{H}_{2} \mathrm{O}$ : Synthesis, characterization, crystal structure, optical and thermal properties. J. Mol. Struct. 2015, 1098, 324-331. [CrossRef]

52. Luo, S.-Y.; Wu, X.-L.; Hu, Q.-P.; Wang, J.-X.; Liu, C.-Z. Structural characterization of a new decavanadate compound with organic molecules and inorganic ions. J. Struct. Chem. 2012, 53, 915-920. [CrossRef]

53. Kioseoglou, E.; Gabriel, C.; Petanidis, S.; Psycharis, V.; Raptopoulou, C.P.; Terzis, A.; Salifoglou, A. Binary Decavanadate-Betaine Composite Materials of Potential Anticarcinogenic Activity. Z. Anorg. Allg. Chem. 2013, 639, 1407-1416. [CrossRef]

54. Riou, D.; Roubeau, O.; Férey, G. Evidence for the Solid State Structural Transformation of the Network-Type Decavanadate $\left(\mathrm{NC}_{7} \mathrm{H}_{14}\right)_{4}\left[\mathrm{H}_{2} \mathrm{~V}_{10} \mathrm{O}_{28}\right]$ into a Lamellar Topology $\left(\mathrm{NC}_{7} \mathrm{H}_{14}\right)\left[\mathrm{V}_{4} \mathrm{O}_{10}\right]$. Z. Anorg. Allg. Chem. 1998, 624, 1021-1025. [CrossRef]

55. Filho, E.V.; Pinheiro, E.M.C.; Pinheiro, S.; Greco, S.J. Aminopyrimidines: Recent synthetic procedures and anticancer activities. Tetrahedron 2021, 92, 132256. [CrossRef]

56. Aureliano, M. The Role of Decavanadate in Anti-Tumour Activity. Glob. J. Cancer Ther. 2017, 3, 12-14. [CrossRef]

57. Sharma, V.; Chitranshi, N.; Agarwal, A.K. Significance and Biological Importance of Pyrimidine in the Microbial World. Int. J. Med. Chem. 2014, 202784, 1-31. [CrossRef] [PubMed]

58. Rehder, D. The potentiality of vanadium in medicinal applications. Future Med. Chem. 2012, 4, 1823-1837. [CrossRef]

59. Cheng, M.; Li, N.; Wang, N.; Hu, K.; Xiao, Z.; Wu, P.; Wei, Y. Synthesis, structure and antitumor studies of a novel decavanadate complex with a wavelike two-dimensional network. Polyhedron 2018, 155, 313-319. [CrossRef]

60. Gu, Y.; Li, Q.; Huang, Y.; Zhu, Y.; Wei, Y.; Ruhlmann, L. Polyoxidovanadate-iodobodipy supramolecular assemblies: New agents for high efficiency cancer photochemotherapy. Chem. Commun. 2020, 56, 2869-2872. [CrossRef]

61. Ksiksi, R.; Abdelkafi-Koubaa, Z.; Mlayah-Bellalouna, S.; Aissaoui, D.; Marrakchi, N.; Srairi-Abid, N.; Zid, M.F.; Graia, M. Synthesis, structural characterization and antitumoral activity of $\left(\mathrm{NH}_{4}\right)_{4} \mathrm{Li}_{2} \mathrm{~V}_{10} \mathrm{O}_{28} \cdot 10 \mathrm{H}_{2} \mathrm{O}$ compound. J. Mol. Struct. 2021, 1229, 129492. [CrossRef]

62. Francés-Monerris, A.; Segarra-Martí, J.; Merchán, M.; Roca-Sanjuán, D. Theoretical study on the excited-state $\pi$-stacking versus intermolecular hydrogen-transfer processes in the guanine-cytosine/cytosine trimer. Theor. Chem. Acc. 2016, 135, 31. [CrossRef]

63. Zhai, H.; Liu, S.; Peng, J.; Hu, N.; Jia, H. Synthesis, crystal structure, and thermal property of a novel supramolecular assembly: $\left(\mathrm{NH}_{4}\right)_{2}\left(\mathrm{C}_{8} \mathrm{H}_{10} \mathrm{~N}_{4} \mathrm{O}_{2}\right)_{4}\left[\mathrm{H}_{4} \mathrm{~V}_{10} \mathrm{O}_{28}\right] \cdot 2 \mathrm{H}_{2} \mathrm{O}$, constructed from decavanadate and caffeine. J. Chem. Crystallogr. 2004, 34, 541-548. [CrossRef]

64. Si, W.; Shen, J.; Zheng, H.; Fan, W. The role and mechanisms of action of microRNAs in cancer drug resistance. Clin. Epigenet. 2019, 11, 25. [CrossRef]

65. Noda, M.F. MicroRNAs in cancer-From research to the clinical practice. Rev. Cubana Med. 2012, 51, 325-335.

66. Feng, Y.-H.; Tsao, C.-J. Emerging role of microRNA-21 in cancer (Review). Biomed. Rep. 2016, 5, 395-402. [CrossRef]

67. Zhao, Z.; Guo, Y.; Liu, Y.; Sun, L.; Chen, B.; Wang, C.; Chen, T.; Wang, Y.; Li, Y.; Dong, Q.; et al. Individualized lncRNA differential expression profile reveals heterogeneity of breast cancer. Oncogene 2021, 40, 4604-4614. [CrossRef]

68. Gilles, M.-E.; Slack, F.J. Let-7 microRNA as a potential therapeutic target with implications for immunotherapy. Expert Opin. Ther. Targets 2018, 22, 929-939. [CrossRef] 
69. Chirshev, E.; Oberg, K.C.; Ioffe, Y.J.; Unternaehrer, J.J. Let-7 as biomarker, prognostic indicator, and therapy for precision medicine in cancer. Clin. Transl. Med. 2019, 8, 1-14. [CrossRef] [PubMed]

70. Bernal, J.D. The Physical Basis of Life. Proc. Phys. Soc. A. 1949, 62, 537-558. [CrossRef]

71. Brack, A. Clay Minerals and the Origin of Life. In Handbook of Clay Science, 2nd ed.; Bergaya, F., Lagaly, G., Eds.; Elsevier: Amsterdam, The Netherlands, 2013; Volume 5, pp. 507-521.

72. Wu, J.; Peng, D.; He, Y.; Du, X.; Zhang, Z.; Zhang, B.; Li, X.; Huang, Y. In Situ Formation of Decavanadate-Intercalated Layered Double Hydroxide Films on AA2024 and their Anti-Corrosive Properties when Combined with Hybrid Sol Gel Films. Materials 2017, 10, 426. [CrossRef]

73. Amante, C.; Sousa-Coelho, D.; Luísa, A.; Aureliano, M. Vanadium and Melanoma: A Systematic Review. Metals 2021, 11, 828. [CrossRef]

74. Scior, T.; Abdallah, H.H.; Mustafa, S.F.Z.; Guevara-García, J.A.; Rehder, D. Are vanadium complexes druggable against the main protease Mpro of SARS-CoV-2?-A computational approach. Inorg. Chim. Acta 2021, 519, 120287. [CrossRef]

75. Bruker. Bruker AXS Inc. V2019.1; Bruker: Madison, WI, USA, 2019.

76. Sheldrick, G.M. SADABS, Program for Empirical Absorption Correction of Area Detector Data; Institute for Inorganic Chemistry, University of Göttingen: Göttingen, Germany, 1996.

77. Sheldrick, G.M. A short history of SHELX. Acta Cryst. 2008, A64, 112-122. [CrossRef] [PubMed]

78. Sheldrick, G.M. Crystal Structure Refinement with SHELXL. Acta Cryst. 2015, C71, 3-8.

79. Dolomanov, O.; Bourhis, L.J.; Gildea, R.; Howard, J.A.; Puschmann, H. OLEX2: A complete structure solution, refinement, and analysis program. J. Appl. Crystallogr. 2009, 42, 339-341. [CrossRef]

80. Spek, A.L. Single-crystal structure validation with the program PLATON. J. Appl. Crystallogr. 2003, 36, 7-11. [CrossRef]

81. Parr, R.G.; Yang, W. Density-Functional Theory of Atoms and Molecules. International Series of Monograph on Chemistry-16; Oxford University Press: New York, NY, USA, 1989.

82. Becke, A.D. Density-functional thermochemistry. III. The role of exact exchange. J. Chem. Phys. 1993, 98, 5648-5652. [CrossRef]

83. Weigend, F.; Ahlrichs, R. Balanced basis sets of split valence and quadruple zeta valence quality for $\mathrm{H}$ to Rn: Design and assessment of accuracy. Phys. Chem. Chem. Phys. 2005, 7, 3297-3305. [CrossRef]

84. Hay, P.J.; Wadt, W.R. Ab initio effective core potentials for molecular calculations. Potentials for the transition metal atoms Sc to Hg. J. Chem. Phys. 1985, 82, 270-283. [CrossRef]

85. Frisch, M.J.; Trucks, G.W.; Schlegel, H.B.; Scuseria, G.E.; Robb, M.A.; Cheeseman, J.R.; Scalmani, G.; Barone, V.; Petersson, G.A.; Nakatsuji, H.; et al. Gaussian 16, Revision, B.; Gaussian Inc.: Wallingford, CT, USA, 2016.

86. Dennington, R.; Keith, T.; Millam, J. Gauss View, Version 6.0.16; Semichem Inc.: Shawnee Mission, KS, USA, 2016.

87. Keith, T.A. TK Gristmill Software, Version 19.02.13; AIMAll: Overland Park, KS, USA, 2019.

88. Turner, M.J.; MacKiinnon, J.J.; Wolff, S.K.; Grimwood, D.J.; Spackman, P.R.; Jayatilaka, D.; Spackman, M.A. CrystalExplorer17. Available online: https:/ / crystalexplorer.scb.uwa.edu.au/ (accessed on 24 July 2021).

89. Morris, G.M.; Huey, R.; Lindstrom, W.; Sanner, M.F.; Belew, R.K.; Goodsell, D.S.; Olson, A.J. AutoDock4 and AutoDockTools4: Automated docking with selective receptor flexibility. J. Comput. Chem. 2009, 30, 2785-2791. [CrossRef]

90. Ortega, E.; Vigueras, G.; Ballester, F.J.; Ruiz, J. Targeting translation: A promising strategy for anticancer metallodrugs. Coord. Chem. Rev. 2021, 446, 214129. [CrossRef] 